\title{
Left Dislocation in Arabic: The complexity of form and meaning
}

\author{
Alexander Andrason \\ Department of African Languages, Stellenbosch University, South Africa \\ E-mail: andrason@sun.ac.za
}

\begin{abstract}
This paper studies the complexity of L(eft) D(islocation). It demonstrates that the function that is crosslinguistically associated with LD is conveyed in Arabic by a set of LD constructions. In the analyzed corpus, these constructions belong to two main types: Clitic LD and Subject LD. Some LD constructions formally and/or functionally overlap with other grammatical categories, especially with fronting. Overall, the absence of a feature proposed for the LD prototype does not imply that a new category, different from LD, must be postulated. The overlap between LD and fronting is explained as a typical effect of language complexity, which can be dealt with if the system of forms and meanings is understood as fuzzy.
\end{abstract}

Keywords: Arabic; left dislocation; fronting

\section{Introduction ${ }^{1}$}

Developed within the frame of cognitive linguistics, the present paper studies the LD construction in the Arabic language and demonstrates a considerable formal and functional complexity of this category.

Cognitive semantics can analyze linguistic reality in two manners. On the one hand, it can study (morphosyntactic) strategies that express a given concept (a meaning or a function), asking what constructions speakers chose to convey determined semantic, functional or pragmatic information. On the other hand, it can examine concepts which a given strategy communicates and observe for what semantic, functional or pragmatic purposes speakers chose a certain construction. The former type, referred to as onomasiology, is equivalent to a "meaning-first" approach and investigates synonymy of forms. The latter type, so-called semasiology, corresponds to a "form-first" approach and deals with the polysemy of a form. Given this methodological alternative, a researcher is faced with the following dilemma: When conducting my study, should I begin with a concept and adopt an onomasiological perspective or, on the contrary, should I start with a form and chose a semasiological perspective (Geeraerts, Grondelaers and Bakema 1994; Geeraerts 2006; Glyn 2010: 18-19)?

\footnotetext{
${ }^{1}$ I would like to thank all the participants of the workshop Left Dislocation organized at Stellenbosch University. I am particularly grateful to C.H.J. van der Merwe, G. Khan, J. Westbury and C. Locatell for their highly valuable comments on the previous version(s) of this paper.
} 
According to linguistic typology - a field that is closely related to cognitive linguistics - "the ultimate solution" is a semantic one (Croft 2003: 13). At the beginning, one adopts an onomasiological attitude and determines the semantic, functional or pragmatic feature that is to be studied, i.e. a piece of information or a type of situation in Croft's terminology. Next, strategies that express that feature and/or are compatible with the posited situation are examined. Only after that, one engages in a semasiological analysis and establishes relations existing between different strategies discovered previously (Croft 2003: 14). This methodological algorithm ensures a less biased perspective. If the research was conducted in the opposite direction, structural criteria could significantly distort the results. That is, as one would a priori exclude types that fail to comply with the formal conditions, linguistic reality would be misrepresented (Croft 2003: 13).

Although the onomasiology-semasiology distinction is important to construct one's argument and/or to follow analyses proposed by others, and although the "meaning-first" and "form-first" approaches can be viewed as methodologically separated whereby the former should theoretically precede the latter, in realistic cases, the division between the two methods is artificial, the line that separates them fuzzy, and their sequentiality problematic (Glyn 2010: 19; Newman 2010). This stems from the fact that form and meaning are always and deeply related, to the degree that (some) meanings become relevant if they are structurally identifiable and that (some) forms are iconic, being called upon by the information they encapsulate.

On the one hand, the fact that a language has a form associated with certain information implies that speakers are aware of the meaning conveyed by that form - the information is relevant to speakers and to the language in question. In other words, the use of a form as an overt and explicit expression of a semantic, a functional and/or a pragmatic feature renders that feature evident and relevant to speakers. On the other hand, semantic, functional and/or pragmatic features can be grammatically encoded in an iconic or cognitively motivated manner. That is, irrespective of their idiosyncrasy, languages may use similar devices to express a determined piece of information, because there is a cognitive link between the information to be conveyed (meaning or function) and the grammatical means that may express it (form). In various cases, this connection is universal, being conditioned by shared cognitive abilities, for instance by embodiment or physical constraints such as the linearity of speech. As a result, a form that is an iconic or cognitively motivated expression of a certain meaning or function can be used to test the accessibility to that meaning or function across languages. In this way, the "form-first" approach can be employed as a primary analysis without rejecting a typological and meaningoriented attitude. Iconic forms are "good candidates" for the analysis of certain meanings because we perceive our reality (constructed of meanings, concepts and functions) through the lenses of linguistic forms.

All of this implies that even though a linguist must decide where (s)he begins his or her study - i.e. whether a form or a meaning will constitute the first step of a scientific endeavor - form and meaning cannot be alienated from each other. Their relational character must be retained. What is more, in the realistic universe - the one we live in and not the one that is abstractly postulated on a scientist's desk - this relationship is deeply intricate to the degree that neither of the two is given first and/or precedes the other. Form and meaning occur simultaneously and are connected in a feedback loop manner, influencing and being influenced by each other. This intricacy stems from the extreme complexity of language (Mufwene 2013; Munné 2013; Bastardas-Boada 2013) and reflects the well-known property of science acknowledged by 
complex-system theory - there is no experiment that is not theory laden and there is no observation without the observer (Hooker 2011; Andrason 2016a). ${ }^{2}$

This intricacy of form and meaning is reflected in the research strategy adopted for this study. The topic of the present workshop was initially semasiological and concerned L(eft) $\mathrm{D}$ (islocation), i.e. a particular grammatical form, be it ideal (a linguistic prototype) or realistic (as attested in a language). Responding to Croft's "meaning-first" program, this article adopts an onomasiological attitude. That is, it investigates how the complex function of (re)activating a referent and indicating its role (pragmatic and syntactic) in a single proposition, crosslinguistically associated with LD, is conveyed in the Arabic language. This onomasiological attitude is, nevertheless, deliberately altered by, once more, the "form-first" method, as the basis of analysis are Arabic translations of the underlying LD constructions (and thus, forms) in Biblical Hebrew.

In order to demonstrate the complexity of the LD construction in Arabic and propose a possible solution with which this complexity can be dealt, the paper will be organized in the following manner. In section 2, the crosslinguistic prototype of LD (both formal and functional) will be presented. In section 3, I will familiarize the reader with main types of LD constructions in Arabic as described in scholarship. In section 4, I will introduce the evidence - the manners in which Arabic translations render the underlying LD construction of the Hebrew Bible. Section 5 will discuss this evidence. In particular, main mapping tendencies between Arabic and Hebrew will be determined and relationships between Arabic LD constructions and other forms of that languages will be noted. At the end of this section, a possible solution to this complex relational network will proposed. Lastly, in section 6, main conclusions will be drawn and lines of future research designed.

\section{The $L D$ form and the $[R+I]$ function}

LD is a grammatical construction that is regularly employed to mitigate a complex cognitive function, namely to first (re)activate a referent characterized by a low degree of accessibility and next to interpret or identify this referent's role in the proposition, be it pragmatic (e.g. topic or focus) or syntactic (e.g. subject, direct object or indirect object; Westbury 2014: 201-202, 214, 340; see Chapter 2). I will refer to this composite task as the [R+I] function.

The $[\mathrm{R}+\mathrm{I}]$ function can, in general, be regarded as a type of message that is highly common in our lives and relates to many daily activities: we (re)introduce a referent that is not easily accessible (metaphorically, we (re)kindle it in our processing memory), and once it is (re)activated, we provide the details of its behavior. Although it is characteristic of various forms of human communication, it is particularly common in language, the principal and the most effective communicative technique adopted by humans.

In cases where the $[\mathrm{R}+\mathrm{I}]$ function appears in a language, it receives a specific shape - a grammatical form. One of possible grammatical contexts in which the $[\mathrm{R}+\mathrm{I}]$ function may be expressed pertains cases where it is communicated within a single proposition. Although the $[\mathrm{R}+\mathrm{I}]$ function, restricted to a mono-propositional environment, can possibly be conveyed in a variety of ways, one manner seems to be the most pervasive. According to Westbury (2014),

\footnotetext{
${ }^{2}$ I draw a comparison between theory/observer and experiment/observation as the former can be viewed as form that contain, receive or communicate the content of the latter.
} 
LD is the most prototypical manner of expressing the $[\mathrm{R}+\mathrm{I}]$ function in a single proposition when the referent is identifiable but only minimally accessible.

Building on typological studies, Westbury (2014: 138-139) convincingly argues that the prototype of this form exhibits the following properties: the dislocate (X), i.e. the element that stands for a (re)activated referent, is external to (or detached from) the matrix clause (M); ${ }^{3}$ the dislocate is encoded by a $\mathrm{N}$ (ominal) $\mathrm{P}$ (hrase), possibly used in an absolute (unmarked) form (casus pendens); the dislocate is co-indexed (i) with an element that is overtly expressed in the matrix clause; this element - be it an argument (e.g. subject or object) or an adjunct - specifies the dislocate's role in the proposition; the co-indexed element is a pronominal $(\mathrm{P})$ and possesses a total identity link $\left(\mathrm{P}_{\mathrm{i}}\right)$ with the dislocate; the dislocate exhibits a special intonation.

The fact that the $[\mathrm{R}+\mathrm{I}]$ function restricted to a single proposition is usually expressed by a LD construction exhibiting properties outlined above - and thus that the proposed LD prototype is pervasive crosslinguistically - is not surprising. This commonness stems from that construction's iconicity. That is, the structure of the LD prototype constitutes an iconic response to the syntactic-pragmatic needs and/or to the type of information that needs to be conveyed. For example, the task of (re)activating a referent is achieved by detaching it linearly (i.e. by placing it at the beginning of the sentence), grammatically (i.e. by employing a "neutral" uninflected or absolute form such as casus pendens) ${ }^{4}$ and phonologically (i.e. by using a pause or particular intonation) from the matrix clause. The task of interpreting the referent's role is attained by overtly employing it in the matrix clause. This means that the dislocate is repeated in the matrix where its pragmatic and syntactic functions are specified. Consequently, the discourse-active item located in the left periphery is necessarily co-indexed with an element of the matrix clause. Although one may repeat the (re)activated referent in the matrix clause, languages avoid such redundancy. Rather, the co-indexation is achieved by means of pronouns, which are exemplary tools to refer to discourse active referents. Thus, once an element is (re)activated, there is no need to reproduce it entirely; rather, by economy, a pronoun referring back to the dislocate is used.

Despite that the LD prototype is an iconic and crosslinguistically pervasive expression of the $[\mathrm{R}+\mathrm{I}]$ function (if it is conveyed in a single proposition), reality is far more complex. Realistic constructions can comply - but do not need to - with all the features postulated for the prototype. In languages and even in a single language, there are constructions expressing some type of the $[\mathrm{R}+\mathrm{I}]$ function that not only closely approximate the postulated prototype but also that are less similar to it, matching uniquely some of the requisites (Westbury 2014). This stems from the fact that a function or a meaning is regularly expressed by a gamut of constructions. Even though some constructions may fully comply with the idealized prototype, others approximate it to a certain degree. Grammatical category, including LD, are radial categories whose members are related via family resemblance. Polysemy of forms and their partial semantic, functional and/or pragmatic overlap constitute a norm across languages (Cuykens and Zawada 2001a, 2001b; Croft and Cruse 2004; Evans and Green 2006; Bybee 2010; Falkum and Vicente 2015; Janda 2015).

\footnotetext{
${ }^{3}$ In further section of this paper, the symbol $\mathrm{M}$ will refer to the matrix verb (i.e. the verb in the matrix clause).

${ }^{4}$ As the (re)activated referent is detached (i.e. dislocated from the matrix), it appears in a type of grammatical

"void", being grammatically unspecified. This explains the use of an unmarked form such as nominative, absolute or casus pendens.
} 
In the following section, I will describe a class of constructions that have been referred to as LD in Arabic scholarship. Although, arguably, all of them are compatible with the $[\mathrm{R}+\mathrm{I}]$ function and have been defined as more or less close instantiation of the LD prototype, they exhibit structural and functional dissimilarities that either approximate them to that prototype or, inversely, distance them from it.

\section{LD in Standard Arabic}

Three main types of LD have been distinguished in Standard Arabic. Two of them, namely, the Clitic LD (cf. section 3.1) and the Nominal LD (cf. section 3.3) approximate the LD prototype to a great extent (Aoun and Benmamoun 1998; Aoun, Benmaoun and Choueiri 2010: 191-201, 208-209; Abdel-Razaq 2011: 41, 50-56, 65-68, 2015; see also Khan 1988: 3-27). The remaining one, the Subject LD does so only to a certain degree (cf. section 3.2; Abdel-Razaq 2011: 45-50). Additionally, there are constructions where the dislocate is marked by a particle. The use of such particles has significant bearing on the relationship of these constructions to the LD prototype (cf. Khan 1988: 5-7; section 3.4). ${ }^{5}$

Traditionally, constructions that in Arabic are labelled as LD are viewed as bi-member topiccomment constructions (Abdel-Razaq 2011: 41, 2015; see also Farghal 1986; Plunkett 1993; Fassi-Fehri 1993; Soltan 2007). They consist of a dislocate (al-mubtada) that introduces the referent (be it activated or reactivated) and a matrix predication (al-khabar) which contains the comment and interprets the pragmatic and syntactic role of the dislocate in the preposition. Thus, even though formulated in different terms by structuralist and generative scholars, the prototypical information conveyed by all LD constructions in Arabic is comparable with the $[\mathrm{R}+\mathrm{I}]$ function. As explained previously, this function is exemplary of the LD prototype (Westbury 2014). ${ }^{6}$

\subsection{Clitic LD}

C(litic) LD is the type of LD that has received the most attention in Arabic, possibly because it approximates the LD prototype to the highest degree (Moutaouakil 1989; Aoun and Benmamoun 1998; Lambrecht 2001: 1063; Alexopoulo, Doron and Heycock 2004: 672; Peled 2009; Aoun, Benmaoun and Choueiri 2010; Abdel-Razaq 2011: 40-45, 2015; Edzard 2013). This construction is illustrated by examples (1.a-f) below. According to modern literature, CLD exhibits the following properties. The dislocate regularly surfaces as a noun phrase that is placed in the left periphery (i.e. at the beginning of the sentence) and (re)activates a referent. ${ }^{7}$ The matrix clause that follows constitutes the comment that specifies the pragmatic and syntactic role of the dislocate. The dislocate is typically co-indexed with a weak pronominal element, the so-called resumptive or clitic pronoun, found in the matrix clause (cf. 1.a; Alexopoulo, Doron and Heycock 2004: 672; Aoun, Benmaoun and Choueiri 2010: 191; Abdel-

\footnotetext{
${ }^{5}$ All these types of LD have been regarded as variants of a broader set of left extraposition by Kahn (1988).

${ }^{6}$ According to Kahn (1988: 31), one of the main functions of LD and extraposed constructions (including SLD) is "to act as a syntactic marker of the boundaries of discourse span". This is compatible with Westbury's view as the marking of boundaries is a regular discursive effect of the pragmatic function of $L D$ (i.e. the $[R+I]$ function; personal correspondence with J. Westbury, September 2015). Kahn's position is further compatible with the theory formulated by Westbury (2014) since in Arabic, the extraposed element is assumed to be familiar to the speaker/writer, being present in his or her long-term memory (Kahn 1988: 51-54).

7 The noun phrase can include full nominals, demonstrative, personal, interrogative and relative pronouns (cf. Kahn 1988: 3-18; regarding the categorial nature of the dislocate, see further below in this paragraph).
} 
Razaq 2011: 42; Edzard 2013: 175). ${ }^{8}$ The dislocate generally appears in casus pendens or nominative (cf. 1.a) ${ }^{9}$ and, being located outside the matrix clause, usually precedes the elements of the complementizer phrase (1.b). ${ }^{10}$ In Standard Arabic, there may be more than one dislocated NP (1.c; Aoun, Benmaoun and Choueiri 2010: 191-192, 209; cf. Khan 1988: 1011). The CLD-ed noun phrase cannot be indefinite. ${ }^{11}$ Accordingly, the dislocate must contain a definite article, demonstrative pronoun or a genitive (the idafa construction), or it appears as a proper name (1.d) and a "strong" pronoun (1.e; Aoun, Benmaoun and Choueiri 2010: 194). ${ }^{12}$ The pronominal element co-indexed with the dislocate can be a direct object (accusative; cf. 1.a-f), an indirect object (dative; 1.c) or a genitive (i.e. adnominal or prepositional) clitic (Aoun, Benmaoun and Choueiri 2010: 200, 209; see also Khan 1988: 18). CLD does not trigger subjectverb inversion (contrary to fronting; cf. section 5.3) and if a focus phrase is used, it must follow the dislocate (1.f; Aoun, Benmaoun and Choueiri 2010: 209). CLD can be schematically represented as $\mathrm{X}_{\mathrm{i}} \mathrm{MP}_{\mathrm{i}}{ }^{13}$

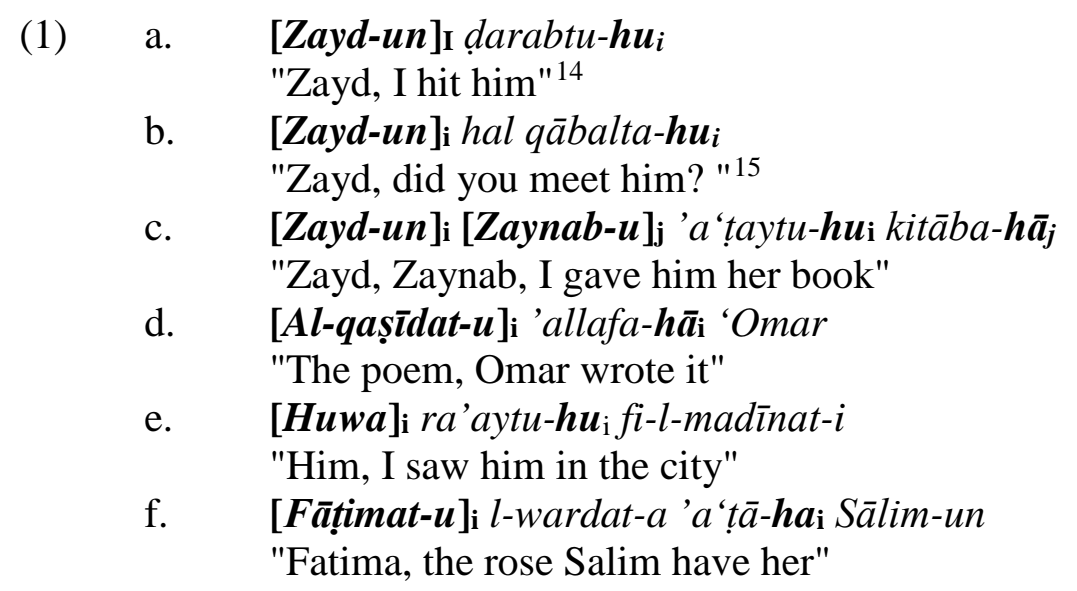

\subsection{Subject LD}

Standard Arabic is a VSO language (2.a; El-Yasin 1985; Dik 1980; Khalil 2000: 135; AbdelRazaq 2011: 46) and a null-subject language (2.b; Soltan 2007; Aoun, Benmaoun and Choueiri

\footnotetext{
${ }^{8}$ In some extraposed constructions, the resumptive elements may be an independent personal pronoun, a demonstrative pronoun or a full nominal. Sometimes, the extraposed element is left unresumed (Kahn 1988: 1922).

${ }^{9}$ There are instances where accusative (which can function in Classical Arabic as an absolute case) can be used and/or is preferable. This is also found when the syntactic role of the resumptive element is other than the direct object (Kahn 1988: 23-26). In other words, the detached nominal in accusative can be resumed by a pronominal clitic in the clause (Zayd-an ra'aytu-hu 'Zayd, I saw him' or Zayd-an marartu bi-hi 'Zayd, I passed by him'; Demirdache 1997: 199). Regarding the case of a dislocated element that is headed by 'ammā and 'inna, see section 3.4, below.

${ }^{10}$ The exception is the embedded context (Aoun, Benmaoun and Choueiri 2010). Rarely, the dislocate may be preceded by an adverb (Khan 1988: 10).

${ }^{11}$ In Classical Arabic, the dislocate may sometimes be indefinite (Khan 1988: 4).

${ }^{12}$ For other properties of the NP (such as the non-sensitivity to islands constraints), see Aoun, Benmaoun and Choueiri (2010: 194-201).

${ }^{13}$ The notation indicates that the pronominal element appears in the postverbal positon. In this schema, the symbol $\mathrm{M}$ stands for the matrix verb.

${ }^{14}$ Adapted from Edzard (2013: 175).

${ }^{15}$ Examples (1.b-f) have been adapted from Aoun, Benmaoun and Choueiri (2010: 191, 206, 194, 195 and 204) respectively.
} 
2010: 59; Abdel-Razaq 2011: 46, 2015). This means that in unmarked verbal clauses, the verb stands first and no overt pronominal subject is necessary. In fact, a sole verb can form a fully grammatical sentence (see again 2.b). Given these two facts, the cases where subject precedes the verb are currently understood as a type of LD - the S(ubject) LD (2.c-d; Plunkett 1993: 241; Soltan 2007; Abdel-Razaq 2011: 46-49; cf. Kahn 1988: 30).

As was the case with CLD, in SLD, the initial noun phrase - which appears in nominative can be viewed as (re)activating a referent that is accessible, being stored in the speaker's memory. Since the matrix clause that follows constitutes a comment that interprets the role of the dislocate, SLD is a manifestation of the $[\mathrm{R}+\mathrm{I}]$ function. ${ }^{16}$ What happens is that while, in the object position, the co-indexed referent (a resumptive pronoun) is obligatory to LD to appear, if the referent is a subject, it does not need to be not overtly expressed, because of the pro-drop rule (cf. 2.c). In other words, the co-indexed pronoun is "a small pro subject" that is non-overt because Arabic is a null-subject language (Plunkett 1993; Abdel-Razaq 2011: 47). This means that the noun phrase found in the preverbal position is not a genuine subject. It rather constitutes a dislocated NP, related to a covert pronominal which is located in the matrix clause (AbdelRazaq 2011: 47-48). Inversely, the subject is a covert/null co-indexed pronominal (a non-overt resumptive pronoun) that belongs to the matrix clause (Soltan 2007; Abdel-Razaq 2011: 4749). ${ }^{17}$ However, the resumptive subject pronoun may sometimes be overtly expressed, as illustrated in example (2.d) (Abdel-Razaq 2011: 46-51). ${ }^{18}$ SLD can be represented with more than one schema: $\mathrm{X}_{i} \mathrm{P}_{\mathrm{i}} \mathrm{M} / \mathrm{X}_{\mathrm{i}} \mathrm{MP}_{\mathrm{i}}$ (if the pronoun is overt) and $\mathrm{X}_{\mathrm{i}} \mathrm{M}\left(\mathrm{P}_{\mathrm{i}}\right)$ (if the pronoun is covert). ${ }^{19}$
a. Yadrus u t-țullāb-u
"The students are studying"20
b. Yadrusūna
"They are studying"
c. [At-tullāb-u $]_{i} y a-d r u s-\bar{n} n a$
"The students, (they) are studying"
d. $\quad$ [Zayd-un]i hadara huwai wa 'aliyy-un
"Zayd, he and Ali came"

\footnotetext{
${ }^{16}$ Concerning functional similarities between CLD and SLD see Kahn (1988).

17 The argumentation is based upon agreement asymmetries that are characteristic of Standard Arabic and the distribution of non-specific indefinite subjects (Aoun, Benmaoun and Choueiri 2010: 57). In general terms, since a null subject appears only in the case of full agreement, the preverbal element that occurs jointly with agreement is not a subject. If it was a subject, there would be two subjects in the sentence: a lexical one and a pronominal one (Aoun, Benmaoun and Choueiri 2010: 60). Concerning syntactic similarities between CLD and SLD that warrant their understanding as "variants of the same basic construction”, see Kahn (1988: 30). For a detailed argumentation concerning the interpretation of subject + verb expressions as variants of LD, consult Aoun, Benmaoun and Choueiri (2010: 57-62) and Abdel-Razaq (2011: 46-51).

${ }^{18}$ The use of an overt pronoun in the preverbal position seems to be more common in two cases: (a) if the role of the dislocate corresponds to the focus; and (b) if the left periphery is a composite, i.e. if the dislocate is qualified by phrases and/or clauses (in such cases, the overt resumptive pronoun does not need to carry any focal sense).

${ }^{19}$ In the schema of covert LD (i.e. $\mathrm{X}_{\mathrm{i}} \mathrm{M}\left(\mathrm{P}_{\mathrm{i}}\right)$ ), the position of the covert pronoun $\left(\mathrm{P}_{\mathrm{i}}\right)$ should not be treated literally as following the matrix verb - as explained, the pronoun is incorporated in the verb itself. In contrast, in a subtype of SLD where the pronoun is expressed overtly, the notation indicates that this pronominal element may appear in a preverbal or postverbal positon in the matrix clause.

${ }^{20}$ Example (2.a) is adapted from Aoun, Benmaoun and Choueiri (2010: 59), (2.c) from Plunkett (1993: 241) and (2.d) from Abdel-Razaq (2011: 48).
} 
Consequently, the two types of LD are equivalent. Both CLD and SLT are expressions of the same functional and structural properties that characterize the LD prototype. Both types express the $[\mathrm{R}+\mathrm{I}]$ function. ${ }^{21}$ As far as the form is concerned, there is a pronominal element in the matrix that is co-indexed with the dislocate. This co-indexed pronominal element identifies the role of the dislocate in the proposition. While the pronoun is often explicitly unexpressed if it acts as subject, in other positions it is obligatory and must appear overtly (Abdel-Razaq 2011: 50). Thus, the difference between CLD and SLD concerns a possible non-overtness of the resumptive subject pronoun in SLD, the presence of which is "overdriven by the null-subject parameter” typical of Arabic (Abdel-Razaq 2011: 51). ${ }^{22}$

\subsection{Nominal LD}

CLD and SLD concern verbal predications (Abdel-Razaq 2011: 50-51). However, in Arabic, LD can also be realized in nominal clauses, i.e. in clauses that do not involve a finite verb (cf. Kahn 1988: 19). ${ }^{23}$ This type of LD will be referred to as the N(ominal) LD and is primarily related to equative constructions, a subgroup of non-verbal predications. NLD exhibits the topic-comment arrangement matching the verbal type of LD - it first (re)activates a less accessible referent and next specifies its role (see example 3.a, below; Abdel-Razaq 2011: 51). As in CDL and SLD, only definite noun phrases are allowed and the dislocate element is obligatorily co-indexed with the pronoun (Abdel-Razaq 2011: 62). ${ }^{24}$ The pronoun is the subject of the predication, while the first noun phrase is a dislocate. ${ }^{25}$ The pronoun found in the matrix identifies the syntactic and pragmatic role of the dislocate (Abdel-Razaq 2011: 66-67; on this type of LD found in Modern Arabic dialects, consult Abdel-Razaq 2011: 50-65).

(3) a. $\quad$ ['Ali $]_{\mathrm{i}}$ huwa al-mudarris-u
"Ali, he is the teacher"
b. Wa-[d-dirham-u $]_{\mathrm{i}}$ huwa $\boldsymbol{a}_{\mathrm{i}}$ lquțbu... ${ }^{26}$
"The dirham is the pivot..."

\footnotetext{
${ }^{21}$ According to the terminology employed in Arabic scholarship, this relation is usually formulated as topiccomment (Abdel-Razaq 2011, 2015).

${ }^{22}$ Accordingly, the covert type of SLD could be regarded as complying with the LD prototype to a lesser degree.

${ }^{23}$ In traditional Arabic grammars, nominal and verbal clauses are defined differently. If the subject precedes the inflected verb, the clause is viewed as nominal. If the verb appears as the first element, the clause is verbal.

${ }^{24}$ In NLD, the pronominal element is always overt. In cases where the resumptive pronoun is unexpressed, the proposition does not constitute a case of $\mathrm{LD}$ and/or the instantiation of the $[\mathrm{R}+\mathrm{I}]$ function. It is rather an unmarked structure composed of the subject and the predicate (Abdel-Razaq 2011, 2015). Accordingly, equatives with an overt pronoun are viewed as a sub-class of SLD that is derived from simple subject-predicate structures, and limited to non-verbal predications (Abdel-Razaq 2011: 55, 66).

${ }^{25}$ According to Kahn (1988: 49-50), the use of a resumptive pronoun in verbless clauses "is conditioned by the individuation of the predicate nominal, [...] as is shown by the fact that they tend to be used before definite nominal or indefinite nominal which are specified by some form of qualifier [...] but not before indefinite unqualified nominal" (ibid.: 50). In tradition scholarship, this pronoun is defined as a copula. Its frequent use between two definite noun phrases would stem from the need to separate the subject from the predicate and, in this manner, to avoid a possible appositive interpretation of the latter (Wright 1964: 258-259; for a critic evaluation of this view see Kahn 1988: 49-50).

${ }^{26}$ Adapted from Kahn (1988: 19).
} 
To conclude, in Arabic, the three types of LD exhibit similar functional and/or structural properties. Although they approximate the LD prototype to distinct degrees, all of them are instances of LD (Abdel-Razaq 2011: 67). ${ }^{27}$

\subsection{LD with a marked dislocate}

To (re)activate a referent and specify its role in a single sentence - i.e. to express the $[\mathrm{R}+\mathrm{I}]$ function which is iconically encoded by the LD constructions discussed in the previous sections - Standard Arabic can also use forms in which the (re)activated entity is marked by particles, especially by 'ammā...fa (3.4.1) and 'inna (3.4.2). ${ }^{28}$

\subsection{1 'ammā...fa}

The first construction is built around the "embracing" bi-member morpheme 'amma (Moutaouakil 2007: 148). This construction is composed of the particle 'ammā 'as for' and the rheme marker fa agglutinated to the following word (Anghelescu 2009: 486; Eisele 2006: 183; Mughazy 2009: 60; Kammensjö 2006: 475). ${ }^{29}$ In Arabic linguistics, this complex locution is viewed as "topic[-]comment articulation par excellence" (Dahlgren 2009: 504) and 'ammā itself as the most common thematizer or topicalization marker (Anghelescu 2009: 486; Eisele 2006: 183). ${ }^{30}$

As has been explained in section 3.1 above, CLD could be regarded as the most prototypical class of LD constructions because the dislocate exhibits reduced case marking, i.e. nominative (Dahlgren 2009: 505; Kammensjö 2006: 475). The construction with the particle 'ammā also assigns nominative case to the dislocated NP. There is, nevertheless, a difference in the use of nominative in these two constructions. While CLD merely uses an "unframed noun phrase" or casus pendens (Kammensjö 2006: 475; cf. Kinberg 1985), the case of the dislocated NP in the 'ammā construction is assigned and required by the particle. This may be observed in the following phenomenon. As explained in section 3.1, it is sometimes preferable to use the dislocate in accusative in CLD (cf. footnote 9, above). However, if an analogous type of construction is headed by 'ammā, nominative is a rule (cf. Kahn 1988: 26). ${ }^{31}$

The dislocate in the 'ammā...fa construction may be co-indexed with an oblique element in the matrix, regularly surfacing as an accusative-genitive resumptive pronoun (4.a; cf. Kahn 1988: 5). In this manner, the formation can be regarded as a type of CLD in which the referent is introduced and (re)activated overtly. It can also be co-indexed with the pronominal subject that precedes the verb, corresponding to SLD (4.b; Kahn 1988: 5). In fact, independent pronouns usually fail to be employed as verbal subjects, with the exception of the 'ammā...fa construction

\footnotetext{
${ }^{27}$ Additionally, scholars identify a vocative type of LD (Lambrecht 2001: 1065; Moutaouakil 1989) yā jārīyātu $m \bar{a}$ smu-ki 'O girl, what is your name?' (Wright 1964: 85) and epithet type of LD (Alexiadou, 2006: 670; Westbury 2014: 136; see also Aoun and Choueiri 2000).

${ }^{28}$ Both types are included by Kahn (1988) as variants of an "extraposed/SV” construction which is a term roughly equivalent to LD used in this article.

${ }^{29}$ Regarding topicalization in Arabic see Dahlgren (2009: 501-510).

${ }^{30}$ As far as the origin of the morpheme 'amma is concerned, the particle derives from a contraction of 'an and $m \bar{a}$.

${ }^{31}$ The particle 'ammā may also introduce a direct object and a prepositional phrase (Kahn 1988: 5).
} 
(Appleyard 2008: 589). The embracing particle 'ammā...fa may also be employed in the nominal class of LD (4.c; Appleyard 2008: 589). ${ }^{32}$

The element $f a$ used to mark the comment is significantly more common in the 'amma $\bar{a}$... $f a$ formation than in other types of LD. However, even here, $f a$ can be sporadically omitted (Kammensjö 2006: 475; see also Kahn 1988: 6). ${ }^{33}$ This is especially evident in Modern Standard Arabic where the use of overt topicalizers such as 'ammā renders the presence of $f a$ optional (Kammensjö 2006: 476; see also Kinberg 1985).

As mentioned above, the 'ammā...fa locution is traditionally regarded as a topic-comment construction like other types of LD. In fact, it constitutes the clearest articulation of this function (Dahlgren 2009: 504). ${ }^{34}$ Kahn (1988: 44) argues that among the extrapolated constructions (which is his terminology to refer to most types of LD), 'amma $\bar{a}$...fa primarily marks a shift in topic. It is a "more powerful topic-shifting device than other types of" LD (ibid.). Accordingly, the 'ammā...fa construction diverges from "bare" CLD, SLD and NLD by drawing attention to the dislocate and by indicating a topic shift instead of marking other discursive boundaries (cf. Kahn 1988: 44). However, the same construction does (re)activates the dislocate and specifies its role in the matrix clause. The dislocate is usually repeated in the commenting matrix clause by a co-indexed resumptive pronoun (4.a; Anghelescu 2009: 486; cf. also Cantarino 1975: III, 196-202). ${ }^{35}$ What happens is that this (re)activation is achieved overtly, i.e. by means of the particle. It is due to the nature of this particle (defined as a topicalizer and/or thematizer) that the 'amma $\bar{a}$...fa construction discursively differs from a "bare" type of LD. Nevertheless, the two constructions do share many other structural and pragmatic properties. ${ }^{36}$

(4) ['Ammā muhammad-un] a. fa-katab-tu la-hu i $_{\mathrm{i}}$ risālat-an 'ams

"As for Muhammad I wrote him a letter yesterday"

b. ['Ammā t-talämidha ] fa-humi yahfạ̣ūna mā yuqaddamu lahum

"As for the students, they memorize what is given to them" ${ }^{37}$

\subsection{2 'inna}

The other construction that overtly marks the dislocated referent makes use of the particle 'inna. The principal function of 'inna in Arabic is to mark focus. It is commonly classified as a (sentential) emphatic particle and translated by 'verily, truly, really, indeed, certainly' (Haywood and Nahmad 1962: 145; Wright 1964: 78; Gully 1995: 125; Bahloul 2008: 164-165; LeTourneau 2006: 349). Depending on a particular semantic-pragmatic category chosen for the

\footnotetext{
${ }^{32}$ When 'ammā...fa appears in nominal clauses, the use of the overt subject pronoun, co-indexed with the dislocate, is optional: 'amm $\mathbf{a}$ l-hakim fa-rajul qawiyy "As for the governor, he [is] a strong man" (Appleyard 2008: 589)

${ }^{33}$ The particle $f a$ is commonly omitted in Judeo-Arabic. There are also cases where wa is used instead of $f a$ in Christian Arabic (Kahn 1988: 6).

${ }^{34}$ Since 'ammā introduces the theme while $f a$ introduces the rheme, the entire construction resembles conditional periods (Bravmann 1953; Anghelescu 2009: 486).

${ }^{35}$ The 'amma...$f a$ construction also conveys the function of contrastive topics and focus extraposition (preposed nominal clause; cf. Dahlgren 2009; McCarus 2008: 260).

${ }^{36}$ The same function can be carried out by constructions such as bin-nisbati li- and 'ammā bin-nisbati li- 'with respect to', fi-mā yata 'allaqu bi-, and fi-mā yakhtașsu bi- 'concerning' (Dahlgren 2009: 504, Anghelescu 2009: 486).

${ }^{37}$ Example (4.a) has been adapted from Eisele (2006: 183) and (4.b) from Appleyard (2008: 589).
} 
analysis, 'inna is defined as a particle of affirmation (Bahloul 2008), assertion (Waltisberg 2006: 468), presentation (Testen 2006: 202), corroboration/confirmation or reinforcement (Dahlgren 2007: 115). Beside its focal role, 'inna can also be employed as a topicalizer or thematizer. This may explain its use in left-dislocated constructions where it conveys the $[\mathrm{R}+\mathrm{I}]$ function in which the referent's activation is achieved overtly. Accordingly, although the function of the (re)activation of an explicit referent is most typically conveyed by 'ammā, it can also be carried out by the particle 'inna with or without the fa heading the commenting matrix clause (Dahlgren 1998: 214-216, 2007: 115, 2009: 504; Fakhri 2006: 649; Kammensjö 2006: 476).

In contrast to 'amma and the other LD constructions discussed so far, in which the dislocate appears in nominative (either constituting an example of casus pendens or being assigned by the heading particle), 'inna governs accusative, requiring the accusative case marking on the dislocate (5.a; Kahn 1988: 7, 23; Bahloul 2008: 164; LeTourneau 2006: 349).

\author{
'Inna š-šams-a mušriqat-un \\ "The sun is indeed shining" (LeTourneau 2006: 349)
}

The commenting predicate may be verbal (a verbal clause) or nominal (Rybalkin 2006: 69). Accordingly, as was the case with the 'ammā...fa construction, the locution composed of 'inna can be viewed as a type of CLD, SLD and/or NLD, overtly marked for (re)activation. According to Kahn (1988: 42), the 'inna construction indicates boundaries of discourse span, similar most other types of LD. ${ }^{38}$

\title{
4. Evidence: Biblical translations
}

As explained in Section 1, meaning and form are connected. As LD is an iconic grammatical means of encoding the $[\mathrm{R}+\mathrm{I}]$ function (if that function is to be conveyed in a single proposition), the "preservation" of the LD structure across languages (e.g. through translations from one to another) may be used in studies on the $[\mathrm{R}+\mathrm{I}]$ function. In other words, the instances where a specific LD form (that is relatively close to the idealized LD prototype) is translated from a source language $l_{1}$ (in which it demonstrably expresses the $[\mathrm{R}+\mathrm{I}]$ function) can provide relevant information concerning how the $[\mathrm{R}+\mathrm{I}]$ function is conveyed in the target language $l_{2}$ that translates from $l_{1}$.

In this section, I will describe the manners in which Standard Arabic treats the instances where the $[\mathrm{R}+\mathrm{I}]$ function is overtly expressed by iconic LD constructions in $\mathrm{B}$ (iblical) $\mathrm{H}($ ebrew). Although all the underlying $\mathrm{BH}$ constructions chosen for the purpose of this study constitute cases of LD and convey the $[\mathrm{R}+\mathrm{I}]$ function, they are semantically, pragmatically and/or structurally different. This non-uniformity aims, in turn, to reveal how the Arabic target language deals with the $[\mathrm{R}+\mathrm{I}]$ function and its grammatical encoding.

\footnotetext{
${ }^{38}$ In this paper, I will treat cases where 'ammā and 'inna appear with what otherwise seems to be similar to CLD or SLD as subtypes of CLD and SLD. The variants where no introductory particle is used, discussed in sections 3.1 (CLD) and 3.2 (SLD), will be referred to as a 'bare' or 'casus pendens' subtype of CLD/SLD. Of course, other manners of categorization could be proposed. Namely, the 'ammā and 'inna constructions could be classified as (entirely) distinct from CLD and SLD, for instance as Marked LD. Given the classification adopted in this article, the schema of CLD that uses the 'ammā ... $f a$ will be noted as 'ammā $\mathrm{X}_{\mathrm{i}} f a-\mathrm{MP}_{\mathrm{i}}$ or 'ammā $\mathrm{X}_{\mathrm{i}} \mathrm{MP}_{\mathrm{i}}$ if $f a$ is missing. In a similar vein, CLD with 'inna will be represented as 'inna $\mathrm{X}_{\mathrm{i}} \mathrm{MP}_{\mathrm{i}}$ (see section 4). For other types of particles that may mark the dislocate and other variants of LD in Arabic consult Kahn (1988).
} 
Consequently, even though the onomasiological analysis is in focus, the empirical study originates not from the meaning (i.e. $[\mathrm{R}+\mathrm{I}]$ function) but rather from the form understood as an iconic expression of that meaning (i.e. LD in Biblical Hebrew where it principally conveys the $[\mathrm{R}+\mathrm{I}]$ function). The translations of the $\mathrm{BH} \mathrm{LD}$ constructions are subsequently used as evidence regarding the treatment of the $[\mathrm{R}+\mathrm{I}]$ function and its grammatical means of expression in the Arabic language. ${ }^{39}$

\subsection{Oblique referent}

The first class of examples consists of cases where the syntactic role of the co-indexed pronominal in the underlying BH LD corresponds to an oblique. That is, the co-indexed pronoun functions as a direct object, an indirect (prepositional) object, or an adnominal determiner. As far as the pragmatic role is concerned, the dislocate usually announces topic (i.e. the referent expressed in the matrix clause is identified as the topic; see examples 6-13), although it may also announce a frame (see example 14).

In general, the $[\mathrm{R}+\mathrm{I}]$ function and the oblique-referent type of LD are well preserved in the Arabic translations. In cases where LD is topic-announcing, the $\mathrm{BH}$ constructions are rendered by means of CLD. The BH LD constructions in examples (6-9), in which the dislocate is a nominal entity further determined by as a relative clause introduced by the pronoun wֶ, are mostly rendered in Arabic by the structure $\mathrm{X}_{\mathrm{i}} \mathrm{MP}_{\mathrm{i}}$. This structure is proper of CLD and fully matches the LD prototype used in the $\mathrm{BH}$ original. To be exact, the dislocate appears as a NP in nominative (casus pendens) and its role is specified by an overt pronominal element found in the matrix clause. In some instances, the dislocate is additionally introduced by means of the particle 'inna (cf. examples $7 \mathrm{NAV}$ and $9 \mathrm{NAV}$ ). As explained in section 3.4.2, this particle necessitates the use of an accusative form of the dislocate. Lastly, in certain instances, LD is not preserved. In such cases, the $[\mathrm{R}+\mathrm{I}]$ function is either encoded by two separate sentences or entirely discounted (6 NAV, GNA, SAB, SAT and 7, 8, 9 SAT).

(6) Deut 14:27

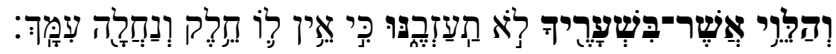

"[As for the Levites resident in your towns $]_{i}$ do not neglect themi" (NRSV)

Wa lā tuhmilū l-lāwiyyīna l-muqīmīna fì muduni-kum (NAV)

Wa-[l-lāwiyyu lladhī fí 'abwāb-i-ka] $]_{i}$ là tatruk-hu $(\mathrm{AVD})$

Wa lā tuhmilū l-lāwiyya lladhì fì muduni-kum (GNA)

Wa lā tuhmilū l-lāwiyyīna lla dhìna fì muduni-kum (SAB)

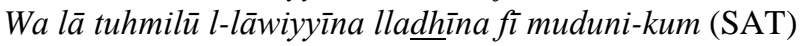

(7) Gen 28:13

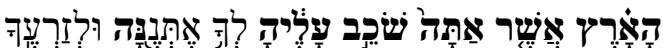

"[The land on which you lie $]_{i}$ to you and to your offspring I am giving iti"

\footnotetext{
${ }^{39}$ For the purpose of this workshop fourteen $\mathrm{BH}$ examples were selected. The objective was to study them in a variety of languages and draw crosslinguistic conclusions. My analysis logically builds on these examples. For the sake of this paper five Arabic translations of the Hebrew Bible were chosen: NAV (New Arabic Version; كتاب (الحياة), AVD (الكتاب المقدس), GNA (Good News; شريف الترجمة العربية المشتركة), SAB (Sharif Bible; الكتاب ) (المقدس، الترجمة العربية المبسطة (لمنة.
} 
'Inna [l-'arḍ-a llatī ta-rqud-u 'alay-hāa $]_{\mathrm{i}}$ lāna 'u'ți-ha $\mathbf{a}_{\mathrm{i}}$ la-ka wa-li-dhurriyyati-ka (NAV)

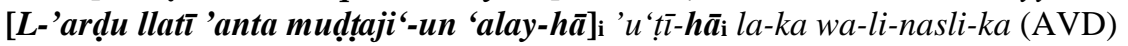

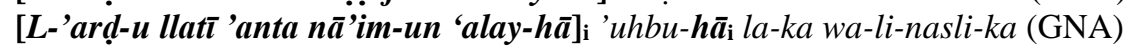

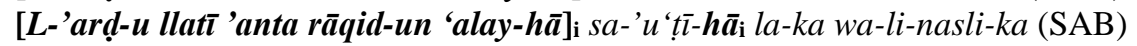

Sa-'u'ți-ka wa-li-nasli-ka l-'arḍa llatī 'anta mudțaji'-un 'alay-hā (SAT)

(8) Gen 35:12

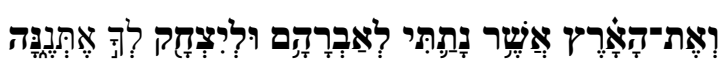

"[The land that I gave to Abraham and Isaac]i to you I will give iti"

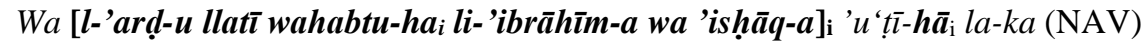

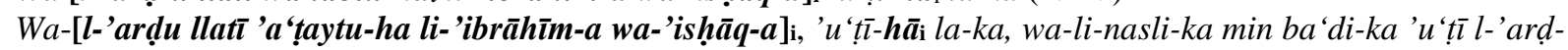
$a$ (AVD)

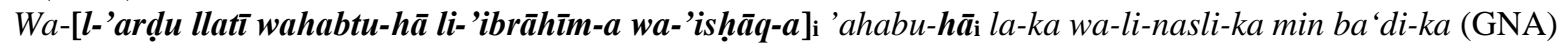

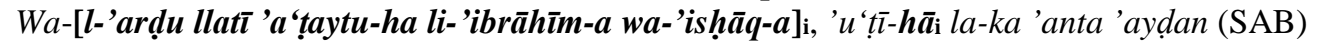

Wa-sa-'u'ți-ka l-'arḍ-a llatī 'a 'ṭaytu-hā li-'ibrāhīm-a wa-'ishăa-i (SAT)

(9) Gen 13:15

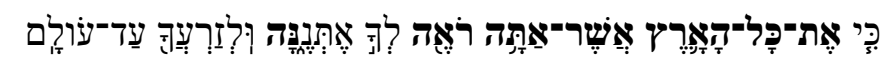

"For [all the land that you see]i to you I will give iti and to you offspring forever"

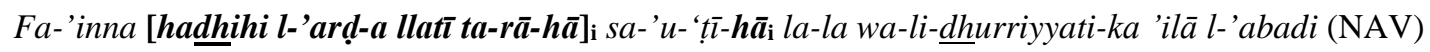

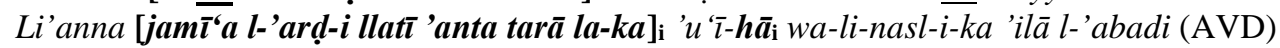

Fa-[hadhini l-'ard-u kullu-hāa $]_{\mathrm{i}}$ 'ahabu-hä $\overline{\mathbf{i}}_{\mathrm{i}}$ la-ka wa-li-nasl-i-ka 'ilā l-'abadi (GNA)

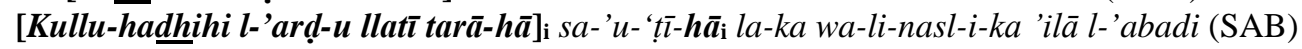

'A-tarā kulla hadhihi l-'arḍ-i? sa-'u-'ți-hä $\bar{a}_{i}$ la-ka wa-li-'hfäd-i-ka mulkan 'ilā l-'abadi (SAT)

A topic-announcing oblique-referent $\mathrm{LD}$ construction and the $[\mathrm{R}+\mathrm{I}]$ function are also relatively well preserved in cases where the dislocate is not a $\mathrm{NP}^{40}$ but rather a phrase built around a relative pronoun (cf. examples 10 and 11) ${ }^{41}$ In such cases, BH LD is regularly rendered as a CLD structure. The dislocate surfaces a relative pronoun: kullu mā, lladhì (na) or man. The (re)activated referent may appear as a bare variant (see examples 10 AVD and GNA) or it may overtly be introduced by the particle 'amma (see examples 11 NAV, AVD, GNA and SAB). In one case, the rheme is not headed by fa even though 'amma is used (see example $11 \mathrm{SAB}$ ). The resumptive pronoun that is co-indexed with the dislocate and that specifies its pragmatic and syntactic role is employed without exception.

(10) Gen. 28:22

"And [all that you give me]i I will surely give one-tenth of iti to you"

Wa-'adfa'u 'ušr-a kull-i mā tarzuqu-nī bi-hi (NAV)

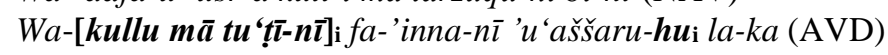

Wa-[kullu mā yahabu-hu lī] ' 'u țī-hui 'ušr-a-hui (GNA)

Wa-'u'ți-ka 'ušr-a kull-i mā tarzuqu-nī bi-hi (SAB)

Wa-sa-'u'ți llāh-a 'ušr-a kull-i šayy-in yu'ți-nī (SAT)

\footnotetext{
40 This NP can itself contain a relative pronoun qualifying the nominal head.

${ }^{41}$ That is, the head is a relative pronominal.
} 

"But [those who did not regard the word of the Lord] $]_{i}$ and left theiri slaves and livestock in the open field"

\author{
'Ammā [lladhīna stakhaffū bi-kalām-i r-rabb-i] $]_{\mathbf{i}}$ fa-qad-tarakū 'abìd-a-humi wa mawāšiy-a-hum fì $_{\mathrm{i}}$-ḥaql-i \\ (NAV) \\ 'Ammā [lladhī lam yuwajjihu qalba-hu 'ilā-kalimat-i r-rabb-i $]_{\mathbf{i}}$ fa-taraka 'abīd-a-hu $u_{\mathrm{i}}$ wa mawāšiy-a-hui fì l-ḥaql- \\ $i$ (AVD)

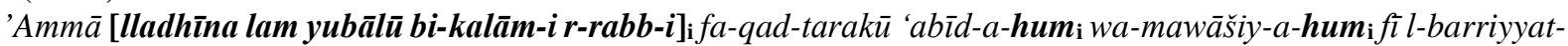 \\ $i$ (GNA)

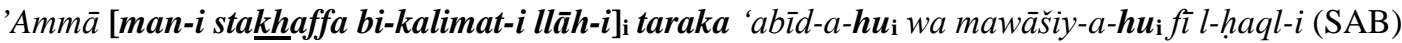 \\ Lakinna [lladhī tajāhala kalimatun llāhi $]_{\mathrm{i}}$ taraka khuddāma-hu wa-mawāšsiy-a-hui 'ilā d-dākhili (SAT)
}

In Biblical Hebrew, the dislocate of a topic-announcing LD construction may also constitute a prepositional phrase as illustrated in examples (12) (NP+ ל 'to/for') and (13) (NP + ע 'from/of'). In Arabic, LD does not tolerate a PP as its dislocate. Therefore, the dislocate resolves into a NP, while its prepositional relation is overtly specified in the matrix clause by means of the pronominal attached to a corresponding preposition 'alä/ay 'to/for' (12) and min 'from/of' (13). Accordingly, BH LD surfaces as CLD in Arabic. In all the translations where LD is retained, the (re)activation of dislocate is overtly communicated by the particle 'amm $\bar{a}$ and the rheme is introduced by fa.

(12) 1 Sam 9:20

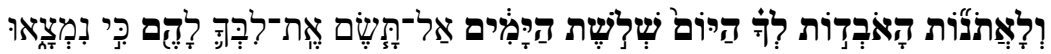
"[As for your donkeys that were lost three days ago $]_{i}$ give no further thought to themi" (NRSV)

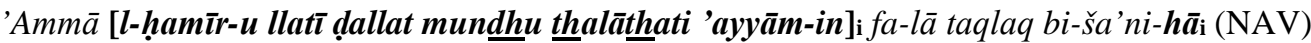

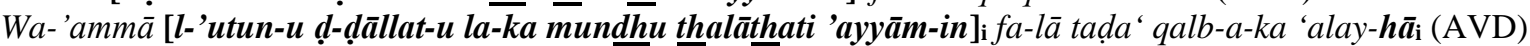

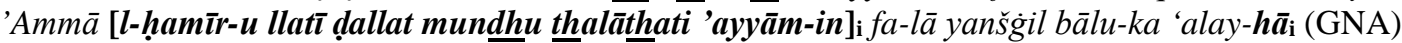

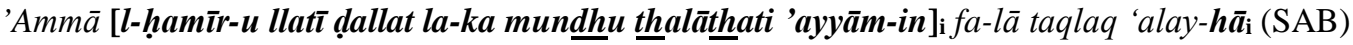

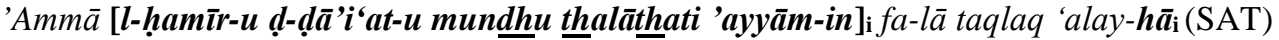

"But [of the tree of the knowledge of good and evil]i you shall not eat of iti"

Kul mā tašă 'u min jamī'i 'ašjār-i l-jannat-i, wa läkin 'iyyaka 'an ta 'kula min šajarat-i ma'rifat-i l-khayr-i wa ššarra (NAV)

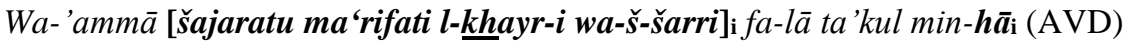

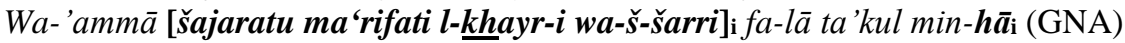

...'Illa šajarata ma 'rifati l-khayr-i wa-š-šarri (SAB)

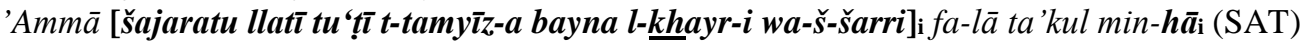

The remaining example of BH LD in which the dislocate's roles in the matrix clause is specified as oblique corresponds to a case where the construction is frame-announcing. That is, the pragmatic role of the referent co-indexed with the dislocate is to present a frame. All the five Arabic translations preserve BH LD by using some type of a CLD structure, additionally marking the (re)activation of the referent (and thus introducing the dislocate) by means of 
'ammā (see example 14 NAV, GNA, SAM and SAT). The bare type of CLD is also used (cf. 14 AVD). ${ }^{42}$ In one case, the dislocate is co-indexed with a full nominal (cf. 14 SAT).

Gen 17:15

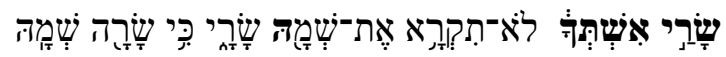

"[As for Sarai your wife] you shall not call heri name Sarai, but Sarah shall be her name"

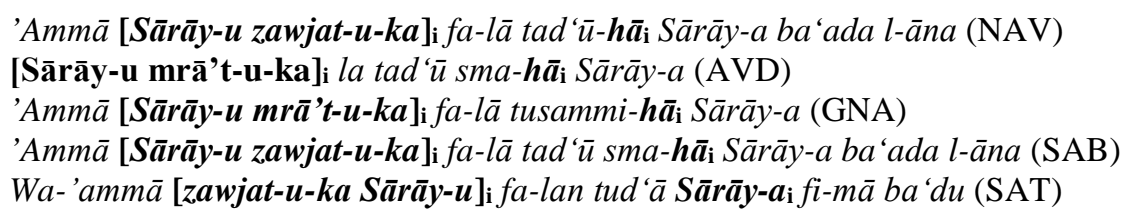

\subsection{Subject referent}

The BH element located in the left periphery can also be specified in the matrix clause as that clause's subject (cf. examples 15-19). These cases found in BH will be referred to as 'subjectreferent' LD.

In BH examples (15), (16) and (17), the dislocate is a NP and announces the topic (Westbury 2014). In (15) and (16), the referent of the LD represents a discourse active entity whose profile is activated. In both examples, the dislocate is co-indexed with an overt pronominal, the subject of the matrix clause.

In order to render this type of LD, Arabic translations regularly employ an SLD construction. In most instances, the pronoun is overtly expressed and placed in the preverbal position. The SLD construction with a covert subject pronoun is also found, especially if the dislocate is short (cf. example 16). In contrast, in cases where the dislocate is long, the resumptive subject pronoun tends to be explicit (cf. example 15). ${ }^{43}$

(15) Gen 24:7

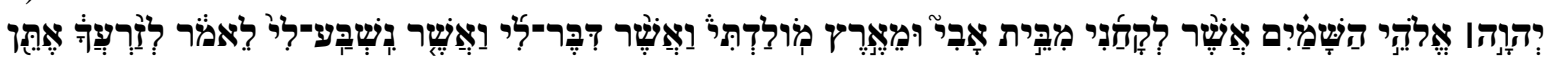

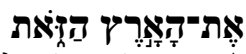

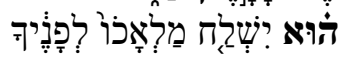

"[The Lord, the God of heaven, who took me from my father's house and from the land of my birth, and who made me a promise and confirm it with an oath, 'To your offspring I give this land' $]_{i}$ he $e_{i}$ will send his angel before you"

Fa-[r-abbu 'ilah-u s-samā 'i lla $\underline{d h} \bar{l}$ 'ajadha-ni min bayt-i 'ab-ī wa min 'arḍ-i qawm-ī, wa khātaba-nī wa 'aqsama

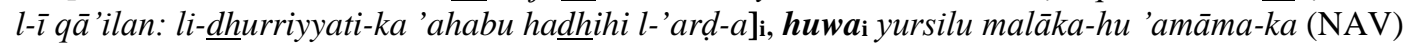

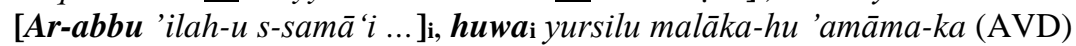

Fa-[r-abbu 'ilah-u s-samā 'i...], huwai yursilu malāka-hu 'amāma-ka (GNA)

[Al-lāh-u r-abbu s-samā 'i...]i, huwai yursilu malāka-hu qaddāma-ka (SAB)

Fa-'ilah-u s-samā' [...]. wa-qad kallama-nī [...]. wa-huwa lladhī sa-yursilu malāka-hu qaddāma-ka [...] (SAT)

\footnotetext{
${ }^{42}$ In two cases, the so-called "sisters of 'inna” are employed: li'anna 'because' (9 AVD) and lakinna 'but' (11 SAT).

${ }^{43}$ In example (16), a focal interpretation is also possible. This focal function may also stimulate the use of a resumptive pronoun in the Arabic translation.
} 
"And [Zilla]i shei too give birth, to Tubal-Cain"

Wa waladat Șillatu “Tūbāla Qāyinna” (NAV)

Wa [Șillatu 'ayḍan] $]_{i}$ waladat(pron) $)_{i}$ "Tūbāla Qāyinna” (AVD)

Wa waladat Sillatu "Tūbāla Qāyinna” (GNA)

Wa [Șillatu] $]_{i}$ waladat(pron) i "Tūbāla Qāyīna” (SAB)

Wa waladat Sillatu "Tūbāla Qāyinna” (SAT)

As was the case with the oblique-referent $\mathrm{LD}$, the topic-announcing dislocate found in the subject-referent LD type may be a relative pronoun with its own clause. In contrast to the examples presented above, the co-indexed pronominal is not overtly expressed. In Biblical Hebrew, this type of LD is viewed as less prototypical (see example 17; Westbury 2014).

In Arabic translations, this type of $\mathrm{LD}$ and the $[\mathrm{R}+\mathrm{I}]$ function are either rendered by SLD with a non-overt co-indexed pronominal or without resorting to a LD structure:

Gen. 44:9

"[The one of you servants with whom this is found $]_{i}$ hei must die"

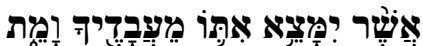

Aan tajid ma'a-hu l-ka's-a min 'abìd-i-ka yamut (NAV)

[-Lladhī yūjadu ma'a-hu min 'abīd-i-ka] $]_{\mathrm{i}}$ yamūtu (pron), (AVD)

'In wajadta l-ka's-a ma'a 'ahad-in min-nā nahnnu 'abìd-i-ka fa-qtul-hu (GNA)

['Ayyu wähid-in min-nā tajidu ma'a-hu l-ka's-a] $]_{\mathrm{i}}$ yamūtu (pron) $\mathrm{i}(\mathrm{SAB})$

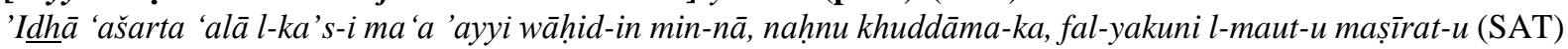

The remaining two cases concern the focus-announcing function of the subject-referent LD construction in Biblical Hebrew. In example (18), the Arabic translations offer two alternatives SLD structures, i.e. with an overt or covert pronominal subject. The former is more frequent appearing three times, while the latter is only found once (SAT). If the pronoun is expressed, it regularly appears in the preverbal position.

(18) Gen. 3:12

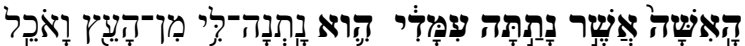

"[The woman you gave to be with me $]_{i}$ shei gave me from the from the tree's fruit and I ate of it"

'Inna-[ha] $]_{i}$ l-mar'atu llatī ja 'alta-hā rafíqatan lī]. hiya $a_{i}$ llatī 'aț'amat-ni min thamari š-šajarat-i fa-'akaltu (NAV)

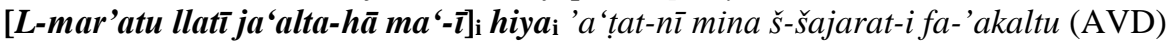

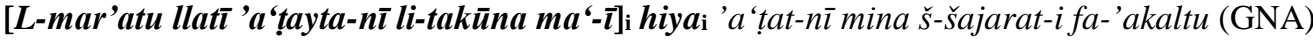

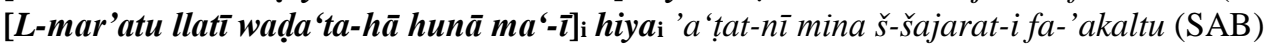

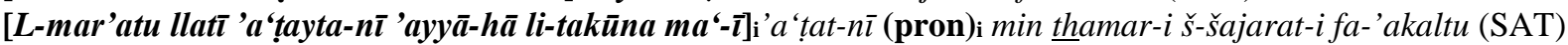

In example (19), the dislocate is a relative pronoun with its own clause and the co-indexed pronoun overtly located in the preverbal position, indicating the focus (Westbury 2014). All the Arabic translations preserve that type of LD by using an SLD structure. The subject pronoun of this SLD structure can be either overt or covert. If an overt pronominal is employed, it occupies the preverbal position. 


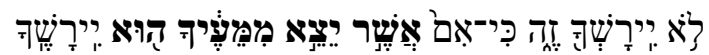
"That one will not be your heir; On the contrary, [one whom you brought forth] $]_{i} \mathbf{h e}_{\mathbf{i}}$ will be your heir"

Lan yakūna hadhā la-ka warīthh-an bal-i [lladhī yakhruju min șulb-i-ka] yakūnu (pro)i warīthh-a-ka (NAV)

... Bal-i [Iladhī yakhruju min 'ahšs̆'-i-ka $]_{i}$ huwai yarithu-ka (AVD)

... Bal [man yakhruju min șulb-i-ka] $]_{i}$ huwa $a_{i}$ lladhī yarithu-ka (GNA)

... Bal-i [bnu-ka lladhi yakhruju min șulb-i-ka $]_{\mathrm{i}}$ yarithu (pro) $\mathrm{i}-k a(\mathrm{SAB})$

... Bal-i [bnu-ka 'anta $]_{i}$ huw $a_{\mathrm{i}} l l a d h \bar{i}$ sa-yarithu-ka (SAT)

\section{Discussion}

\subsection{Results}

The Arabic evidence shows that in most cases, BH LD is preserved and the $[\mathrm{R}+\mathrm{I}]$ function is expressed in one proposition. Overall, LD appears in 71\% of the Arabic examples. It is absent in $29 \%$. The presence of LD constructions is different in the five translations chosen for the purpose of this study. AVD employs an LD construction in all the 14 cases, AVD and GNA in 11 cases, NAV in 8 cases, and SAT in 6 cases.

In general, if the $[\mathrm{R}+\mathrm{I}]$ function is to be conveyed in a single proposition, it is expressed in Arabic either by CLD or SLD. The former is commonly marked by (re)activation particles, such as 'ammā and 'inna. The latter never uses such introductory morphemes. The CLD structure is a regular response to the instances where the dislocate is identified in the matrix as an object or an adnominal complement. The SLD structure appears in cases where the dislocate's role is specified as the subject of the matrix clause. In this manner, the data provided in section 4 corroborate the presence of the two types previously associated with LD in Arabic (narrowed to verbal clauses) and their subtypes that overtly mark the dislocate.

If the dislocate is identified with the oblique-role, the CLD structure may surface in three possible variants, depending on the shape of the left periphery and the grammatical manner of the (re)activation of the referent. First, the dislocate can be a bare referent $\left(\mathrm{X}_{\mathrm{i}}\right)$ presented as nominative casus pendens without an overt (re)activation particle (i.e. $\mathrm{X}_{\mathrm{i}} \mathrm{MP}_{\mathrm{i}}$ ). Second, the dislocate $\mathrm{X}_{\mathrm{i}}$ may be headed by the particle 'amma $\bar{a}$ that overtly marks its (re)activation (i.e. 'amma $\left.\mathrm{X}_{\mathrm{i}}(f a-) \mathrm{MP}_{\mathrm{i}}\right)$. In this construction, the particle 'ammā assigns the nominative case to the dislocated NP. Third, the dislocate can be introduced by the particle 'inna, taking an accusative case ending ('inna $\mathrm{X}_{\mathrm{i}} \mathrm{MP}_{\mathrm{i}}$ ). The two former types are common, exhibiting a comparable regularity: $\mathrm{X}_{\mathrm{i}} \mathrm{MP}_{\mathrm{i}}=33 \%$ and 'ammā $\mathrm{X}_{\mathrm{i}}(f a-) \mathrm{MP}_{\mathrm{i}}=36 \%$. The third type ('inna $\left.\mathrm{X}_{\mathrm{i}} \mathrm{MP}_{\mathrm{i}}\right)$ is significantly less frequent and amounts to $4 \%$. In the remaining $27 \%$, LD is not preserved. The co-indexed pronominal element that specifies the role of the dislocate (if the LD is preserved) is consistently used. It regularly occupies the postverbal position. On one occasion, the dislocate is co-referred with an identical nominal entity instead of a pronominal clitic ('amma $\mathrm{X}_{\mathrm{i}}$ ( $f a$ ) $\mathrm{MX}_{\mathrm{i}}$ ). In one instance, $f a$ is absent even though 'ammā heads the dislocate. Among all the three subtypes, the variant that uses the topicalizer 'inna diverges from the LD prototype the most, as the dislocate appears in accusative. Another structure that diverges from the LD prototype is the construction where the co-indexed referent is a full nominal and identical to the dislocate. 
If the dislocate corresponds to the subject of the matrix clause, LD is preserved in $68 \%$ of the examples. In such cases, the SLD construction may surface in two sub-types: in one type, the subject is overt $\left(X_{i} P_{i} M\right)$, in the other type, the subject is covert $\left(X_{i} M\left(P_{i}\right)\right)$. The overt-subject variant displays a slightly higher frequency than the covert-subject variant, namely $X_{i} P_{i} M=$ $40 \%$ and $\mathrm{X}_{\mathrm{i}} \mathrm{M}\left(\mathrm{P}_{\mathrm{i}}\right)=28 \% .{ }^{44}$ In the remaining 32\%, the LD construction is not employed. If the subject pronoun is overtly expressed, it always occupies the preverbal position. In all the instances of SLD, the dislocate appears as casus pendens failing to be additionally marked by 'ammā...fa or 'inna, which are common in the oblique-type or CLD. There are no instances of the use of the particle $f a$ in SLD.

The limited evidence suggests that in the subject-referent LD type, the presence of an overt coindexed pronoun may be stimulated by two factors: the dislocate's discourse-pragmatic role is to provide focus and/or the dislocate is a complex and long sequence. ${ }^{45}$ In both cases, the pronoun is overt, being regularly located in the preverbal position. This, in turn, may suggest that (at least hypothetically) the overt pronoun may be used even if no focal function is involved or if, from the perspective of information structure, the presence of an LD construction is not necessary (e.g. the referent is discourse active and fully accessible). In such cases, the presence of an overt subject pronoun may rather be motivated by the length of the dislocate. ${ }^{46}$ The empirical information is summarized by the following table:

\begin{tabular}{|l|l|l|l|l|}
\hline NAV & AVD & GNA & SAB & SAT \\
\hline
\end{tabular}

$\mathrm{i}=$ oblique $>$ CLD

\begin{tabular}{|c|c|c|c|c|c|}
\hline 6 & & $\mathrm{X}_{\mathrm{i}} \mathrm{MP}_{\mathrm{i}}$ & & & \\
\hline 7 & 'inna $\mathrm{X}_{\mathrm{i}} \mathrm{MP}_{\mathrm{i}}$ & $\mathrm{X}_{\mathrm{i}} \mathrm{MP}_{\mathrm{i}}$ & $\mathrm{X}_{\mathrm{i}} \mathrm{MP}_{\mathrm{i}}$ & $\mathrm{X}_{\mathrm{i}} \mathrm{MP}_{\mathrm{i}}$ & \\
\hline 8 & $\overline{\mathrm{X}_{\mathrm{i}} \mathrm{MP}_{\mathrm{i}}}$ & $\mathrm{X}_{\mathrm{i}} \mathrm{MP}_{\mathrm{i}}$ & $\mathrm{X}_{\mathrm{i}} \mathrm{MP}_{\mathrm{i}}$ & $\mathrm{X}_{\mathrm{i}} \mathrm{MP}_{\mathrm{i}}$ & \\
\hline 9 & 'inna $\mathrm{X}_{\mathrm{i}} \mathrm{MP}_{\mathrm{i}}$ & $\mathrm{X}_{\mathrm{i}} \mathrm{MP}_{\mathrm{i}}$ & $\mathrm{X}_{\mathrm{i}} \mathrm{MP}_{\mathrm{i}}$ & $\mathrm{X}_{\mathrm{i}} \mathrm{MP}_{\mathrm{i}}$ & \\
\hline 10 & & $\mathrm{X}_{\mathrm{i}} \mathrm{MP}_{\mathrm{i}}$ & $\mathrm{X}_{\mathrm{i}} \mathrm{MP}_{\mathrm{i}}$ & & \\
\hline 11 & 'ammā $\mathrm{X}_{\mathrm{i}}$ fa-MP $\mathrm{MP}_{\mathrm{i}}$ & 'ammā $\mathrm{X}_{\mathrm{i}}$ fa-MP $\mathrm{MP}_{\mathrm{i}}$ & 'ammā $\mathrm{X}_{\mathrm{i}}$ fa-MP $\mathrm{MP}_{\mathrm{i}}$ & 'ammā $\mathrm{X}_{\mathrm{i}} \mathrm{MP}_{\mathrm{i}}$ & $\mathrm{X}_{\mathrm{i}} \mathrm{MP}_{\mathrm{i}}$ \\
\hline 12 & 'ammā $\mathrm{X}_{\mathrm{i}}$ fa-MP $\mathrm{MP}_{\mathrm{i}}$ & 'ammā $\mathrm{X}_{\mathrm{i}}$ fa-MP $\mathrm{MP}_{\mathrm{i}}$ & 'ammā $\mathrm{X}_{\mathrm{i}}$ fa-MP $\mathrm{MP}_{\mathrm{i}}$ & 'ammā $\mathrm{X}_{\mathrm{i}}$ fa-MP $\mathrm{MP}_{\mathrm{i}}$ & 'ammā $\mathrm{X}_{\mathrm{i}}$ fa-MP $\mathrm{MP}_{\mathrm{i}}$ \\
\hline 13 & & 'ammā $\mathrm{X}_{\mathrm{i}}$ fa-MP ${ }_{\mathrm{i}}$ & 'ammā $\mathrm{X}_{\mathrm{i}}$ fa-MP & & 'ammā $\mathrm{X}_{\mathrm{i}}$ fa-MP \\
\hline 14 & 'ammā $\mathrm{X}_{\mathrm{i}}$ fa-MP $\mathrm{MP}_{\mathrm{i}}$ & $\mathrm{X}_{\mathrm{i}} \mathrm{MP}_{\mathrm{i}}$ & 'ammā $\mathrm{X}_{\mathrm{i}}$ fa-MP & 'ammā $\mathrm{X}_{\mathrm{i}}$ fa-MP & 'ammā $\mathrm{X}_{\mathrm{i}}$ fa-MX \\
\hline
\end{tabular}

\footnotetext{
${ }^{44}$ Their relative frequency is $59 \%\left(\mathrm{X}_{\mathrm{i}} \mathrm{P}_{\mathrm{i}} \mathrm{M}\right)$ versus $41 \%\left(\mathrm{X}_{\mathrm{i}} \mathrm{M}\left(\mathrm{P}_{\mathrm{i}}\right)\right)$

${ }^{45}$ If the dislocate's pragmatic function in the proposition is to provide focus, then the placement of the subject pronoun in the preverbal position is self-explanatory.

${ }^{46}$ In this paper, the correlation between the length of the subject and the presence of an overt pronoun before the verb is only suggested. Certainly, more data are necessary and larger corpora must be studied. The few examples analyzed in this article that point to this relationship are not sufficient to formulate a valid rule. However, the hypothesis concerning the connection between the subject's length and the presence of a resumptive subject pronoun, without being necessitated by the focal or $[\mathrm{R}+\mathrm{I}]$ functions, may be supported by crosslinguistic evidence. I have noticed this connection in my own studies on Polish and Spanish. In Polish, if the subject is long, a resumptive subject pronoun is used despite the fact that it is discourse active and fully accessible, and a focal function is not involved. In contrast, if the subject is short (and it is discourse active and fully accessible), the presence of resumption is unnatural, unless the subject is in focus.
} 
$\mathrm{i}=$ subject $>\mathrm{SLD}$

\begin{tabular}{|l|l|l|l|l|l|}
\hline 15 & $X_{i} P_{i} M$ & $X_{i} P_{i} M$ & $X_{i} P_{i} M$ & $X_{i} P_{i} M$ & \\
\cline { 1 - 1 } & \multirow{2nnnnn}{*nnnn}{16} & $X_{i} M\left(P_{i}\right)$ & & $X_{i} M\left(P_{i}\right)$ & \\
& & $X_{i} M\left(P_{i}\right)$ & $X_{i} M\left(P_{i}\right)$ & \\
\hline 18 & & $X_{i} P_{i} M$ & $X_{i} M$ & $X_{i} P_{i} M$ & $X_{i} P_{i} M$ \\
\hline 19 & $X_{i} M\left(P_{i}\right)$ & $X_{i} P_{i} M$ & $X_{i} M\left(P_{i}\right)$ & \\
\hline
\end{tabular}

Table 1: Arabic renderings of BH LD constructions that exhibit the $[\mathrm{R}+\mathrm{I}]$ function ${ }^{47}$

\subsection{Mapping BH LD onto Arabic constructions}

The $[\mathrm{R}+\mathrm{I}]$ function evident in $\mathrm{BH}$ LD constructions is rendered by a variety of Arabic forms: casus pendens CLD $\left(\mathrm{X}_{\mathrm{i}} \mathrm{MP}_{\mathrm{i}}\right)$, 'ammā CLD ('ammā $\left.\mathrm{X}_{\mathrm{i}}(f a)-\mathrm{MP}_{\mathrm{i}}\right)$, 'inna CLD ('inna $\mathrm{X}_{\mathrm{i}} \mathrm{MP}_{\mathrm{i}}$ ), overt-subject SLD $\left(\mathrm{X}_{\mathrm{i}} \mathrm{P}_{\mathrm{i}} \mathrm{M}\right)$ and covert-subject SLD $\left(\mathrm{X}_{\mathrm{i}} \mathrm{M}\left(\mathrm{P}_{\mathrm{i}}\right)\right){ }^{48}$ These forms approximate the structural LD prototype to distinct degrees. The type referred to as casus pendens or bare CLD is the closest match of the LD prototype, while 'amma CLD and 'inna CLD comply with that prototype to a lesser extent. The last one, especially, seems to deviate from the prototype as it uses both an additional morpheme and requires an accusative ending on the dislocate. ${ }^{49}$ The covert-subject SLD type may also be regarded as diverging from the prototype since the coindexation between referents is not explicit. Overall, this divergence from the LD prototype is mainly related to the presence of additional particles ('ammā and 'inna) and/or non-compliance with certain traits postulated for that prototype. Such absent traits can be an unmarked form of the dislocate (casus pendens or nominative) or a resumptive pronoun co-indexed with the dislocate.

Even though all these structures can be used to convey the $[\mathrm{R}+\mathrm{I}]$ function and translate BH LD constructions, they are not synonymous. The lack of their total equivalence stems from the fact that each of these LD locutions has a slightly distinct functional (or semantic) potential if the form is envisaged in its totality. Merely speaking, even though the Arabic constructions mentioned above perform similar functions in certain contexts (as demonstrated by the translations studied in this paper), they also serve other and, sometimes, opposite purposes. As explained in section 3.4, some of them can express values different from those associated with $\mathrm{LD}$ (i.e. the $[\mathrm{R}+\mathrm{I}]$ function). This "deviant" function is principally conditioned by the presence of additional elements (e.g. morphemes or particles) that have their own semantic, functional and/or pragmatic content. It is this content that potentially "infects" the meaning of the entire LD construction. Because of compositionality effects, it modifies the value of an LD construction in cases where it is employed to render the $[\mathrm{R}+\mathrm{I}]$ function of the underlying $\mathrm{BH}$ text. Furthermore, this content associated with each particle distinguishes the Arabic LD constructions among themselves (in addition to other structural dissimilarities). It further

\footnotetext{
${ }^{47}$ The grey color represents cases where LD is not preserved in the Arabic translations. The numbers refer to the examples.

${ }^{48}$ Two other varieties are also found: 'ammā $\mathrm{X}_{\mathrm{i}} f a-\mathrm{MP}_{\mathrm{i}}$ and 'ammā $\mathrm{X}_{\mathrm{i}} f a-\mathrm{MX}_{\mathrm{i}}$.

${ }^{49}$ It may, however, correspond to lexicalization (or the use of an 'additional' morpheme), which is attested across languages, e.g. in English "as far as $x$ is concerned'. Such lexicalization may require the use of cases other than nominative and casus pendens (cf. jeśli chodzi o + genitive in Polish).
} 
removes some LD constructions from the LD prototype if one assumes the pairing of the prototype of form (LD) with the prototype of meaning (the $[\mathrm{R}+\mathrm{I}]$ function). This is most evident if one compares a bare type of CLD with the varieties introduced by 'ammā and 'inna, as these two particles may also communicate functions for which a bare type LD is unmarked. ${ }^{50} \mathrm{~A}$ similar contrast exists between overt-subject SLD and the variant in which the subject is unexpressed. ${ }^{51}$

When LD constructions that in BH express the [R+I] function are to be translated into Arabic, Arabic employs its own language-specific grammatical devices that are compatible with the $[\mathrm{R}+\mathrm{I}]$ function. Since no two forms are entirely equivalent in two different languages (and/or in a single language), any Arabic structure that renders the $\mathrm{BH}$ original adds some additional information to the $[\mathrm{R}+\mathrm{I}]$ function, found in the $\mathrm{BH}$ text. Arguably, the more formally distinct a given Arabic construction is from BH LD and from the LD prototype, the greater the extent of this additional "noise" seems to be. Thus, two forms that are compatible with the same semantic domain (as any of the Arabic LD constructions are) and that can be used in an identical or highly similar context, do not necessarily produce the same effect. Instead, each one "colors" the meaning expressed in that context by its own (inherent) semantic, functional and/or pragmatic potential.

\subsection{LD and Fronting}

The evidence suggests that some of LD constructions may structurally and functionally overlap with $\mathrm{F}$ (ronting). As far as the structure is concerned, this overlap is mainly related to the pronominal element co-indexed with the dislocate.

First, the overt subject pronoun may appear in the preverbal position in cases where LD is topicannouncing. In these instances, the resumptive pronominal element does not communicate focus although it appears in the position typically associated with focus (cf. example 15). The use of the resumptive element is rather motivated by syntax, particularly the length of the dislocate. However, the same structure can be used to render a focus-announcing type of LD. Consequently, under certain conditions, topic-announcing and focus-announcing SLD may exhibit analogous structures in Arabic. This, in turn, means that the presence of an overt pronoun in the preverbal position in SLD in Arabic is not a conclusive indicator of its focal role, typically associated with $\mathrm{F}^{52}$

Second, there are cases where the dislocate is not "resumed" by an overt subject pronoun in SLD. Accordingly, the surfacing structure could be viewed as identical to $\mathrm{F} .{ }^{53}$ That is, on certain

\footnotetext{
${ }^{50}$ In section 3.3, it was pointed out that 'ammā can function as a thematizer and/or topicalizer and 'inna may act as a focus marker and topicalizer.

${ }^{51}$ An overt-subject SLD can also communicate a focal function (see section 5.3 below).

52 Compare the case of Xhosa discussed in this volume (Andrason and Visser 2016).

${ }^{53}$ According to Aoun, Benmaoun and Choueiri (2010: 203-209) LD is distinguishable in Arabic from the fronting construction by the following traits: fronting preserves the case marking of the corresponding gap on the entity in the left periphery (Fâtimat-u l-wardat-a 'a'ța-ha saalim-un 'Fatima, the ROSE Salim gave her') while LD generally bears nominative; fronting triggers obligatory subject - verb inversion (kitāb-an 'ištarat zaynab-u 'It is a book that Zaynab bought'); in fronting, the dislocate can be indefinite while LD must be definite (qașidat-un 'allafa 'omar 'A poem, Omar wrote'); fronting is not limited to NPs but also concern PP, VP and AP; there is only one focused (fronted) phrase in a clause, while there may be multiple dislocate elements in LD; a fronted element is related to a gap inside the clause, while the dislocate in LD is related to a co-indexed pronominal; the fronted
} 
occasions, the focal or topical functions, which are regularly expressed by $\mathrm{F}$, and the $[\mathrm{R}+\mathrm{I}]$ function, which is typically associated with LD, may resort to the same construction. ${ }^{54}$ It is only the wider information structure and/or the larger discourse that enable us to discern the correct interpretation, i.e. either as focus/topic (thus F) or $[\mathrm{R}+\mathrm{I}]$ (thus LD). ${ }^{55}$ This of course can be achieved under the assumption of the pairing of the prototype of structure with the prototype of meaning. While CLD seems to be clearly distinguishable from F (in CLD the use of a coindexed resumptive pronoun is obligatory), SLD is less so. In cases where the left element is indefinite, only $\mathrm{F}$ is possible if the overt resumptive pronoun is absent: šay'un jā'a bi-ka 'SOMETHING has brought you' (Wright 1964: 263) or baqarat-un takallamat 'an ox has spoken' (ibid.). However, if the left-element is definite two readings are possible: one with the covert resumptive subject pronoun (SLD) Zayd-un māta '[As for Zayd] (he $_{\mathrm{i}}$ ) died' and the other with no resumption (F) '[It was] ZAYD [who] died' (Wright 1964: 255). ${ }^{56}$ In various cases, this ambiguity can be clarified because of a specific function conveyed by the construction, i.e. focus/topic or $[\mathrm{R}+\mathrm{I}]$. If the pronoun subject is expressed overtly, one deals with LD, especially if the dislocate is short: ${ }^{57}$ Zayd-un mäta huwa '[As for Zayd] $]_{i}$ he ${ }_{i}$ died' (Wright 1964: 255) or Zayd-un hadhara huwwa wa 'aliyy-un '[Zayd] $]_{\mathrm{i}}$, he $\mathrm{i}_{\mathrm{i}}$ and Ali came’ (Abdel Razaq 2011: 48).

F and LD can also overlap with respect to their function. Namely, in cases where the idea of contrast is to be expressed, both F and LD structures can be used. Compare wa-qawm-un qāla - wa-qawm-un qāla 'some say - others say' (Wright 1964: 263) and 'ammā Zayd-un fa-māta wa-'ammā 'umar-u fa-hayya 'Zayd died - Umar lived' (Wright 1964: 255). The former sentence is an unequivocal case of $\mathrm{F}$ - according to the standard definitions of F and LD, only F can concern an indefinite NP. The latter sentence constitutes an example of LD (specifically, SLD with an overtly marked (re)activation of the referent). ${ }^{58}$ In some situations, this overlap between LD and F may render the categorical distinction of the two constructions fuzzy.

element necessarily follows the dislocate; the prototypical function of fronting is focus while the prototypical function of $\mathrm{LD}$ is $[\mathrm{R}+\mathrm{I}]$ (this statement does not hold true for $\mathrm{BH}$ where the typical function of fronting is topic shift); fronting is sensitive to island constraints, whereas LD is not.

54 Consequently, the presence of the resumptive pronoun and/or its lack cannot be treated as decisive in distinguishing between $\mathrm{LD}([\mathrm{R}+\mathrm{I}])$ and $\mathrm{F}$ (focus/topic), even though the former case characterizes LD while the latter is typical of F. On the one hand, there are cases of LD where the resumptive pronoun is not overtly expressed (covert-pronoun SLD). On the other hand, there are cases where the resumptive pronoun can be used but LD and $[\mathrm{R}+\mathrm{I}]$ do not need to be involved, as the use of the pronoun may, at least to a certain degree, be conditioned by the length of the "to-the-left" element.

55 Another indicator can be intonation.

${ }^{56}$ According to the standard generative view, this sentence would be a case of LD. However, even by using the generative argumentation, this example could be regarded as ambiguous. Namely, LD is typically postulated on the ground of full agreement (cf. section 3.2). This is evident for plural referents, as there would be a full agreement with the verb if the nominal precedes the verb. However, for a singular referent, it is difficult to conclude whether one deals with a full or partial type of agreement, since the partial agreement reduces the feature of plurality to the singular. In other words, the full and partial agreements exhibit exactly the same form in the singular.

${ }^{57}$ If the dislocate is long the pronoun may be used as a void resumptive, i.e. resumptive necessitated by syntax rather than pragmatics. In fact, this structure can be used in cases where the $[\mathrm{R}+\mathrm{I}]$ function is conveyed. Thus, although the form of the expression would be identical to an overt-subject SLD $\left(X_{i} S_{i} M\right)$, it would not be a case of LD under the assumption of the paring of form (LD) and meaning (the $[\mathrm{R}+\mathrm{I}]$ function).

58 The overlap of F and LD with respect to a contrastive function seems to be a more universal phenomenon (see Lambrecht 1994: 292-296; Westbury 2014: 88-89, 148-151, 159, 174-175, 291-192 and 198-200). It is significant that in an exemplary case found in Deuteronomy 18.14 (Westbury 2014: 327-328), all the Arabic translations use the 'ammā CLD expression, which is also used to render the topic-announcing BH LD (cf. Andrason and Visser 2016; Andrason 2016b). 
Overall, the less prototypical and iconic a given LD form is, the more exposed to other functions - and thus to overlap with other categories - it is.

\subsection{Complexity and fuzziness}

The evidence demonstrates the complexity of the relationship between form(s) (the LD constructions) and meaning(s) (the $[\mathrm{R}+\mathrm{I}]$ function). Forms and meanings overlap and differ, delivering a network of unimaginable intricacy.

In general terms, the relationship between form and meaning is as 'many-to-many' - one meaning is mapped onto various forms and one form maps various meanings. ${ }^{59}$ This renders forms and meanings found in a language less neat, graspable and definable than is usually postulated in linguistic models. A great bulk of this complexity stems from the fact that a construction can express different meanings and that a meaning can be encoded by different constructions. It also derives from the fact that realistic (language-specific) constructions match formal and functional prototypes only to a certain degree.

As each construction has a complex internal content (be it semantic, functional and/or pragmatic) and a composite structural configuration (being composed of several atomic elements), it relates to other constructions in a different manner. Because of this dissimilar connectivity, the systemic status of any two constructions is always distinct. Thus, they are never entirely identical.

The relationship of forms and meanings has three main effects. First, as a grammatical construction diverges from the structural prototype associated with a given meaning, it is "exposed" to other meanings. Second, constructions that are compatible with a given meaning, regularly color that meaning by their own properties contained in their broadly understood semantic potential. Third, as is the case of a structural prototype, which is an abstract and idealized construct, the meaning to be activated can be viewed as an abstract and idealized semantic domain. In realistic instances, it will always be "infected" by the noise that is produced by the semantic potential of the employed constructions.

The only manner to deal with the infinite complexity of forms and meanings is to adopt a fuzzy perspective, typical of studies of complex systems. That is, one postulates a few robust and salient prototypes and, by using the idea of family resemblance, navigates through a vast number of transition-phases in which realistic exemplars are found. Even though prototypes are abstract and, to a degree, arbitrary, they are necessary to comprehend and explain reality, be it linguistic or extra-linguistic. However, prototypes are not discrete, neat and static boxes containing realistic elements, such as forms and meanings. Their role is rather to demarcate the extents of continua within which realistic forms and meanings exist. As reality is infinitively complex, language cannot be viewed (even in models) as neat and tidy. Its components cannot be separated by crisp boundaries. Boundaries in realistic systems are fuzzy. Reality is full of transition phases - it is "messy".

Consequently, instead of classifying realistic constructions as either LD or non-LD, one should rather determine their location on the continuum that links the LD prototype to its opposite or

\footnotetext{
${ }^{59}$ Many-to-many relationships are typical or complex systems (cf. Bishop 2010:123 and Moreno, Ruiz-Mirazo, and Barandiaran 2011:327).
} 
to a distinct category (e.g. F). This continuum includes constructions that match the LD prototype and those that do not comply in any aspect with the LD prototype, through a gamut of transition-phase constructions that comply with that prototype to a certain degree. The gradual scale of belonging and non-belonging not only concerns the LD structure, but may also be used to study the information typically associated with $\mathrm{LD}$, i.e. the $[\mathrm{R}+\mathrm{I}]$ function. Realistic constructions can be viewed as more or less prototypical expression of the $[\mathrm{R}+\mathrm{I}]$ function depending on their intrinsic properties (semantic, functional and pragmatic potential). Given the close connection of forms and meanings, the two continua are related.

Additionally, this representation presupposes a stage where a construction exhibits an intermediate profile. At this stage, a construction mixes properties characteristic of the two extreme poles of the continuum and, thus, of the two prototypes (e.g. LD and F). In such cases, the taxonomical status of a construction is transitory.

\section{Conclusion}

This paper analyzed the expressions of the $[\mathrm{R}+\mathrm{I}]$ function in Arabic, if this function was to be expressed in a single proposition. The evidence reveals a great complexity of LD as far as its formal/functional properties and relationships to other forms and functions are concerned.

In accordance with the underlying $\mathrm{BH}$ text and typological tendency, the $[\mathrm{R}+\mathrm{I}]$ function is usually conveyed by a set of LD constructions that are more or less iconic and that comply with the LD prototype to a lesser or greater extent. These constructions are: CLD (with its three variants depending on the properties of the dislocate: a bare casus pendens NP, an NP marked by an overt (re)activation marker 'ammā, and an NP introduced by 'inna) and SLD (with its two subtypes depending on the fact whether the subject pronoun is overtly expressed or not).

The data demonstrate that some LD constructions are formally similar to other constructions associated with distinct meanings or functions. Moreover, certain LD constructions may overlap functionally with other constructions, and may thus be used to encode other types of information. This formal and functional overlap is most evident if LD is compared to F.

Furthermore, the presence of some features that usually seem to be viewed as decisive for classifying a construction as LD need not be crucial to LD to occur. Inversely, the lack of a prototypical feature does not mean that a construction should be defined as a distinct category. For instance, the presence of resumption does not necessarily imply LD, and its absence does not automatically trigger $\mathrm{F}$. This formal and functional overlap is a typical effect of language complexity.

This complexity can arguably be dealt with if the system of forms and meanings is understood not as neat and tidy, but as fuzzy, i.e. built around idealized prototypes and connected via "smooth" transition phases.

Although this study has shed some new light on LD constructions in Arabic, it has its own limitations. The most evident is the extent of the analyzed corpus. I discussed only fourteen $\mathrm{BH}$ examples and 70 Arabic tokens (14 x 5 translations). Even though certain tendencies have been revealed and the cases studied in this paper constitute a promising testing sample, the corpus cannot be viewed as representative and the proposed principles cannot be regarded as definitive. 
Accordingly, more extensive corpus analyses are need. Additionally, this paper indicates the necessity for a more in-depth study concerning the relation between LD and F (and between $[\mathrm{R}+\mathrm{I}]$ and topic/focus).

\section{References}

Abdel-Razaq, I. 2011. Who is What and What is Who: The Morpho-syntax of Arabic WH. PhD dissertation, University of London.

Abdel-Razaq, I. 2015. Who is What and What is Who: the Morphosyntax of Arabic WH Cambridge: Cambridge Scholars Publishing.

Alexiadou, A. 2006. Left dislocation (including CLLD). In M. Everaert and H. C. van Riemsdijk (Eds.) Blackwell's Companion to Syntax, Vol. 2. Malden, MA: Blackwell. pp. 669699.

Alexopoulou, T., E. Doron and C. Heycock. 2004. Broad subjects and clitic-left dislocation. In D. Adger, C. De Cat and G. Tsoulas (Eds.) Peripheries: Syntactic Edges and their Effects. Dordrecht: Kluwer. pp. 329-358.

Andrason, A. 2016a. A Complex System of Complex Predicates: Tense, Taxis, Aspect and Mood in Basse Mandinka from a Grammaticalization and Cognitive Perspective. PhD dissertation, Stellenbosch University.

Andrason, A. 2016b. To resume or not to resume: Some remarks on 'resumption' in left dislocation constructions in Polish, and its relevance for Biblical Hebrew. Stellenbosch Papers in Lingusitics Plus 50. 185-199.

Andrason, A. and M.W. Visser. 2016. The mosaic evolution of Left Dislocation in Xhosa. Stellenbosch Papers in Lingusitics Plus 50. 139-158.

Aoun, J. and E. Benmamoun 1998. Minimality, reconstruction and PF movement. Linguistic Inquiry 29. 569-592.

Aoun, J., E. Benmamoun and L. Choueiri. 2010. The Syntax of Arabic. Cambridge University Press.

Aoun, J. and L. Choueiri. 2000. Epithets. Natural Language and Linguistic Theory 18. 1-39.

Anghelescu, N. 2009. Theme/Rheme. In K. Versteegh (Ed.) Encyclopedia of Arabic Language and Linguistics. Vol. 4. Leiden: Brill. pp. 484-487.

Appleyard, D. 2008. Personal pronoun (Standard Arabic). In K. Versteegh (Ed.) Encyclopedia of Arabic Language and Linguistics. Vol 3. Leiden: Brill. pp. 588-593.

Bahloul, M. 2008. Structure and Function of the Arabic Verb. London: Routledge. 
Bastardas-Boada, A. 2013. Sociolinguistics: towards a complex ecological view. In À. MassipBonet and A. Bastardas-Boada (Eds.) Complexity Perspectives on Language, Communication and Society. Heidelberg: Springer. pp. 15-34.

Bishop, R. 2011. Metaphysical and epistemological issues in complex systems. In C. Hooker (Ed.) Philosophy of Complex Systems. Amsterdam: Elsevier. pp. 105-136.

Bravmann, M. M. 1953. Studies in Arabic and General Syntax. Cairo: Institut Français d’Archéologie Orientale.

Bybee, J. 2010. Language, Usage and Cognition. Cambridge: Cambridge University Press.

Cantarino, V. 1975. Syntax of Modern Arabic Prose: The Expanded Sentence. Bloomington: Indiana University Press.

Croft, W. 2003. Typology and Universals. Cambridge: Cambridge University Press.

Croft, W. and D. Cruse. 2004. Cognitive Linguistics. Cambridge: Cambridge University Press.

Cuykens, H. and B. Zawada. 2001a. Introduction. In H. Cuykens and B. Zawada (Eds.) Polysemy in Cognitive Linguistics. Amsterdam: John Benjamins. pp. i-xxvii.

Cuykens, H. and B. Zawada. (Eds.) 2001b. Polysemy in Cognitive Linguistics. Amsterdam: John Benjamins.

Dahlgren, S. O. 1998. Word Order in Arabic. Gothenburg: Acta Universitatis Gothoburgensis.

Dahlgren S. O. 2007. Focus. In K. Versteegh (Ed.) Encyclopedia of Arabic Language and Linguistics. Vol 2. Leiden: Brill. pp. 113-116.

Dahlgren, S. O. 2009. Topicalization. In K. Versteegh (Ed.) Encyclopedia of Arabic Language and Linguistics. Vol 4. Leiden: Brill. pp. 501-508.

Demirdache, H. 1997. Dislocation, resumption and weakest crossover. In E. Anagnostopoulou, H. van Riemsdijk and F. Zwarts (Eds.) Materials on Left-Dislocation. Amsterdam: John Benjamins. pp. 193-231.

Dik, S. 1980. Studies in Functional Grammar. London: Academic Press.

Edzard, L. 2013. The philological approach to Arabic grammar. In J. Owens (Ed.) The Oxford Handbook of Arabic Linguistics. Oxford: Oxford University Press. pp. 165-184.

Eisele, J. 2006. Argument. In. K. Versteegh (Ed.) Encyclopedia of Arabic Language and Linguistics. Vol 1. Leiden: Brill. pp. 182-1 87.

El-Yasin, M. K. 1985. Basic word order in Classical Arabic and Jordanian Arabic. Lingua 65. 107-122. 
Evans, V. and M. Green. 2006. Cognitive Linguistics: An Introduction. Edinburgh: Edinburgh University Press.

Geeraerts, D. 2006. Words and Other Wonders: Papers on Lexical and Semantic Topics. Berlin: Mouton de Gruyter.

Fakhri, A. 2006. Discourse analysis. In K. Versteegh (Ed.) Encyclopedia of Arabic language and Linguistics. Vol 1. Leiden: Brill. pp. 647-653.

Falkum, I. and A. Vicente. 2015. Polysemy: current perspectives and approaches. Lingua 157. $1-16$.

Farghal, M. 1986. The Syntax of Wh-questions and Related Matters in Arabic. PhD dissertation, Indiana University.

Fassi-Fehri, A. 1993. Issues in the Structure of Arabic Clauses and Words. Dordecht: Kluwer.

Geeraerts, D., S. Grondelaers and P. Bakema. 1994. The Structure of Lexical Variation. Meaning, Naming, and Context. Berlin: Mouton de Gruyter.

Glyn, D. 2010. Corpus-driven cognitive semantics introduction to the field. In D. Glyn and K. Fischer (Eds.) Quantitative Methods in Cognitive Semantics: Corpus-Driven Approaches,. Berlin: De Gruyter Mouton. pp. 1-41.

Gully, A. 1995. Grammar and Semantics in Medieval Arabic: A Study of Ibn-Hisham's 'Mughni l-Labib'. Richmond: Curzon Press.

Haywood, J. A. and H. M. Nahmad. 1965. A New Arabic Grammar. London: Lund Humphries.

Kammensjö, H. 2006. Connectives. In K. Versteegh (Ed.) Encyclopedia of Arabic Language and Linguistics. Vol 1. Leiden: Brill. pp. 470-477.

Khalil, E. 2000. Grounding in English and Arabic News Discourse. Amsterdam: John Benjamins.

Khan, G. 1988. Studies in Semitic Syntax. Oxford: Oxford University Press.

Kinberg, N. 1985. Adverbial clauses as topics in Arabic: Adverbial clauses in frontal position separated from their main clauses. Jerusalem Studies in Arabic and Islam 6. 353-416. (Reprinted in L. Kinberg and K. Versteegh. (Eds.) 2001. Studies in the Linguistic Structure of Classical Arabic. Leiden: Brill. pp. 43-102.)

Lambrecht, K. 1994. Information Structure and Sentence Form: Topic, Focus, and the Mental Representations of Discourse Referents. Cambridge: Cambridge University Press

Lambrecht, K. 2001. Dislocation. In M. Haspelmath, E. Konig, W. Oesterreicher and W. Raible (Eds.) Typology and Language Universals. Vol. 2. Berlin: de Gruyter. pp. 1050-1078. 
LeTourneau, M. 2006. Case theory. In K. Versteegh (Ed.) Encyclopedia of Arabic Language and Linguistics. Vol 1. Leiden: Brill. pp. 347-353.

McCarus, E. 2008. Modern Standard Arabic. In K. Versteegh (Ed.) Encyclopedia of Arabic Language and Linguistics. Vol 3. Leiden: Brill. pp. 238-262.

Moreno, A., K. Ruiz-Mirazo, and X. Barandiaran 2011. The impact of the paradigm of complexity on the foundational frameworks of biology and cognitive science. In C. Hooker (Ed.) Philosophy of Complex Systems. Amsterdam: Elsevier. pp. 311-334.

Moutaouakil, A. 1989. Pragmatic Functions in a Functional Grammar of Arabic. Dordrecht: Foris.

Moutaouakil, A. 2007. Functional Grammar. In K. Versteegh (Ed.) Encyclopedia of Arabic Language and Linguistics. Vol 2. Leiden: Brill. pp. 143-150.

Mufwene, S. 2013. The emergence of complexity in language: An evolutionary perspective. In À. Massip-Bonet and A. Bastardas-Boada (Eds.) Complexity Perspectives on Language, Communication and Society. Heidelberg: Springer. pp. 197-218.

Mughazy, M. 2009. Relative clause. In K. Versteegh (Ed.) Encyclopedia of Arabic Language and Linguistics. Vol 4. Leiden: Brill. pp. 60-70.

Munné, F. 2013. The Fuzzy Complexity of Language. In À. Massip-Bonet and A. BastardasBoada (Eds.) Complexity Perspectives on Language, Communication and Society. Heidelberg: Springer. pp. 175-196.

Newman, J. 2010. Balancing acts: Empirical pursuits in cognitive linguistics. In D. Glyn and K. Fischer (Eds.) Quantitative Methods in Cognitive Semantics: Corpus-Driven Approaches. Berlin: De Gruyter Mouton. pp. 79-99.

Peled, Y. 2009. Sentence Types and Word Order Patterns: Medieval and Modern Perspectives. Leiden: Brill.

Plunkett, B. 1993. The position of subjects in Modern Standard Arabic. In M. Eid and C. Holes (Eds.) Perspectives on Arabic Linguistics V. Amsterdam: John Benjamins. pp. 231-260.

Rybalkin, V. 2006. 'Amal. In K. Versteegh (Ed.) Encyclopedia of Arabic Language and Linguistics. Leiden: Brill. pp. 67-74.

Soltan, U. 2007. On Formal Feature Licensing in Minimalism: Aspects of Standard Arabic Morphosyntax. PhD dissertation, University of Maryland.

Testen, D. 2006. Assertive particle. In K. Versteegh (Ed.) Encyclopedia of Arabic Language and Linguistics. Vol 1. Leiden: Brill. pp. 201-204.

Waltisberg, M. 2006. Conjunctions. In K. Versteegh (Ed.) Encyclopedia of Arabic Language and Linguistics. Vol 1. Leiden: Brill. pp. 467-470. 
Westbury, J. 2014. Left-Dislocation in Biblical Hebrew: A Cognitive Linguistic Account. PhD dissertation, Stellenbosch University.

Wright, W. 1896-1898/2005. Arabic Grammar. Mineola: Dover Publications INC.

Arabic sources:

AVD = Arabic Revised Van Dyke Bible (الكتاب المقدس). 1999. Bible Society of Egypt. Consulted at www.bible.com/versions/13-avd-lktb-lmqds

GNA = Good News Arabic Bible (الترجمة العربية المشتركة). 1993. Bible Society in Lebanon. Consulted at https://www.bible.com/versions/67-gna-ltrjm-at-lrby-at-lmshtrk-at

NAV = Holy Bible, New Arabic Version (كتاب الحياة). 1988-1997. Biblica. Consulted at https://www.bible.com/versions/101-nav-ktb-lhy-at

SAB = Sharif Bible (نشريف). 2000. International Sharif Bible Society. Consulted at https://www.bible.com/versions/153-sab-shryf

SAT = Easy-To-Read Version Arabic Bible (الكتاب المقس، الترجمة العربية المبسطة). 2009. World Bible Translation Center. https://www.bible.com/versions/195-sat-lktb-lmqds-ltrjm-at-lrby-at$\underline{\text { lmbst-at }}$ 